\title{
Pension Plan Funding and Stock Market Efficiency
}

\author{
FRANCESCO FRANZONI and JOSÉ M. MARÍN *
}

\begin{abstract}
The paper argues that the market significantly overvalues firms with severely underfunded pension plans. These companies earn lower stock returns than firms with healthier pension plans for at least five years after the first emergence of the underfunding. The low returns are not explained by risk, price momentum, earnings momentum, or accruals. Further, the evidence suggests that investors do not anticipate the impact of the pension liability on future earnings, and they are surprised when the negative implications of underfunding ultimately materialize. Finally, underfunded firms have poor operating performance, and they earn low returns, although they are value companies.
\end{abstract}

\footnotetext{
${ }^{*}$ Francesco Franzoni: Department of Finance, HEC School of Management, 1 rue de la Liberation, Jouy en Josas, 78351, France; José M. Marín: Department of Economics and Business, Universitat Pompeu Fabra (UPF), and CREA, c. R. Trias Fargas 25-27, Barcelona, 08005, Spain. The authors are grateful to Wayne Ferson, Ulrich Hege, Harrison Hong, Jonathan Lewellen, Randall Morck, Jacques Olivier, and Bruno Solnik, Robert Stambaugh (the editor), and an anonymous referee for helpful comments. F. Franzoni is also a member of GREGHEC, CNRS unit, FRE 2810. J. M. Marín acknowledges financial support from the Spanish Ministry of Science and Technology (BEC2002-00429 Grant) and from the BBVA Foundation.
} 
The combination of a deep bear stock market and a sharp fall in interest rates during the period 2000 to 2002 has resulted in a $\$ 400$ billion deterioration of the funding status of defined benefit (DB) pension plans in the U.S. The gravity of this phenomenon is such that the research divisions of several investment firms started the calendar year 2003 with a report on corporate pension funding and accounting. As one might expect, the main theme of these reports is whether or not current market valuations correctly reflect this liability and its implicatons for future corporate cash flows. ${ }^{1}$

The correct valuation of the corporate pension liability does not concern only stock market efficiency; indeed it has macroeconomic implications. Unlike continental Europe and Japan, the U.S. pension system has shifted most of the burden of providing income for people's retirement from the public to the private sector. In particular, the U.S. system is special in its heavy reliance on pension plans in which companies, rather than individuals or the public sector, bear all the responsibility of the provision of funding for employee retirement. Although economists and the media have mostly focused on the serious dangers that public pension systems currently face, such as the increase in longevity and the fall in birth rates, we cannot take for granted that the U.S. private pension system does not face problems. At the heart of the viability and the efficiency of the U.S. system is the correct pricing of companies, so that the flow of savings into corporate securities is not distorted and efficient levels of corporate investment in capital and employment are obtained. The relationship between corporate pension provision and economic efficiency is described in Bulow, Morck, and Summers (1987):

The question of how the stock market values pension assets and liabilities is of central importance to corporate decision makers, financial economists and economists concerned with [the] level of national savings. If investors treat pension debt different from other forms of debt, in valuing firms, prudent value maximizing managers should recognize these differences and adjust their pension funding policies accordingly. A convincing demonstration that market valuations failed to take account of pension assets or liabilities would either challenge prevailing theories of market efficiency and rational valuation, or force a re-examination of conventional views about effective ownership of pension claims. Finally, if potential beneficiaries of pensions recognized the value of the pensions and adjusted their savings accordingly, but no comparable adjustment occurred because holders of pension liabilities did not recognize their liabilities [...], then pensions would reduce national savings. 
This article finds evidence of significant overvaluation for companies with large deficits in their DB pension plans. When we sort companies into portfolios on the basis of the funding level of their pension plan, the decile portfolio of most underfunded companies earns lower returns than portfolios of firms with healthier pension plans. Adjusting for risk makes the gap even larger, as severely underfunded firms have relatively high loadings on the three Fama and French (1993) factors. The estimated underperformance for the most underfunded portfolio with respect to the three-factor model can be as large as $10.6 \%$ annually. The returns are persistently low for at least five years after the emergence of underfunding.

Using time-series and cross-sectional tests, and relying on other descriptive evidence, we conclude that this finding is not the effect of known asset pricing anomalies such as price momentum (Jegadeesh and Titman (1993)), earnings momentum (Chan, Jegadeesh, and Lakonishok (1996)), or accruals (Sloan (1996)). Instead, as we explain below, we believe the overvaluation follows from the fact that investors do not take into account the negative implications of pension plan underfunding for future earnings and cash flows until they actually materialize in the income statement. Consistent with this interpretation, we provide significant evidence that the market is negatively surprised by the low earnings of underfunded firms.

By looking at several measures of operating and financial performance, we characterize the most underfunded companies as poor performers. This fact, along with the evidence that they have high book-to-market $(\mathrm{B} / \mathrm{M})$ ratios, characterizes the mispricing that identify in this paper as an anomaly that is inherently different from the "value vs. growth puzzle." Severely underfunded companies are poor past performers, which, unlike other high B/M firms, seem to be overvalued. We believe that the implications of this result for the debate on the nature of the value premium are far-reaching.

In a DB pension plan, the assets are represented by the contributions made by the sponsoring firm over the life of the plan. As these contributions are normally invested in traded assets, they are valued at their market prices. The liability of a pension plan is the discounted value of all future pension obligations. The discount rate is chosen by the company and it is related to the level of interest rates. A pension plan underfunding occurs when the value of liabilities exceeds the value of assets. It can materialize as a consequence of a decline in the market value of pension assets, of a decrease of the rate at which future obligations are discounted, or simply because the value of new contributions is not enough to cover new obligations. In any case, the deficit in the plan represents a true liability for the sponsoring company both in economic and accounting terms, as 
it has to appear on the balance sheet. ${ }^{2}$

There are two main channels through which pension liabilities affect earnings and cash flows. First, according to accounting regulations, if a loss emerges in a pension plan as a consequence of reduced assets or increased liabilities and the loss is larger than $10 \%$ of the maximum between the two items, then the company is obliged to amortize the loss starting from the next fiscal year. ${ }^{3}$ This amortization decreases earnings of firms with severely underfunded plans. Cash flows are also reduced if at the same time the company makes a financial contribution to the plan. Secondly, the Employee Retirement Income Act (ERISA) of 1974, which protects workers' interests in the solvency of the plan, imposes a mandatory contribution if the plan is severely underfunded. ${ }^{4}$ In this case, the sponsoring company is required to make up the deficit within three to five years of its emergence. Overall, the institutional environment causes large pension liabilities to ultimately affect earnings and cash flows. The crucial point is that this impact may not be immediate, but it can be delayed to the year following the first emergence, and can hit earnings and cash flows even five years later. Also important, the discretion with which the firm may decided both the amount of the amortization and the contributions to the plan, along with the intricate set of accounting and fiscal regulations, make the impact of the pension liability difficult to assess ex ante.

In our view, these institutional features play a major role in the emergence of the overvaluation of underfunded firms and the subsequent negative earnings surprises and price adjustments. The reason behind the overvaluation is that investors do not fully incorporate into prices the negative impact of a large pension liability on future earnings and cash flows. When the pension liability starts to affect earnings and cash flows, the market appears to be negatively surprised. In this sense, the evidence of low returns for companies with high past underfunding would be a manifestation of the price adjustment that follows the negative surprises. Moreover, the fact that the impact of a large pension underfunding on earnings and cash flows can manifest up to five years after its occurrence would explain why returns are persistently low for a number of years.

We provide abundant evidence in support of this interpretation. First, several indicators suggest that a negative earnings surprise can be predicted for companies with large past underfunding. We find that these firms have negative raw and risk-adjusted returns around future earnings announcements, negative standardized unexpected earnings (SUE), and downward revisions in analyst forecasts of earnings. Secondly, earnings and cash flows deteriorate in the year after the emergence of a large underfunding, and this phenomenon is not accompanied by a decrease in the growth rate of sales. In other words, there are factors outside the normal operations of the firm that cause the 
poor economic result. We believe that these factors are the amortization of the pension loss and the contributions to the plan.

On the other hand, there is no evidence of a symmetric effect for firms with overfunded pension plans. This is not surprising and can be explained on the basis of existing theories of manager short-termism (see, for example, Stein (1989)). Since the firm can use the overfunding to increase current earnings and cash flows, it is likely that there is no delay between the materialization of the overfunding and its positive impact on the economic performance of the firm.

A priori, we can identify a number of factors that potentially magnify the mispricing related to a given level of underfunding. First, and most obvious, a given dollar amount of pension liability has different relevance depending on the potential of a company to generate future cash flows that are needed to cover the shortfall in the pension plan. Since market value is related to future cash flows, the same amount of underfunding should have less importance for a larger company. Second, if indeed the market does not pay enough attention to pension information, the mispricing is likely to emerge among those companies for which there is less information diffusion, that is, smaller companies. Finally, the same percentage decline in cash flows can have a larger impact on the market value of a firm that relies more heavily on cash flows to finance projects with positive net present value (NPV). In other words, credit constraints can magnify the price impact of a given surprise in earnings. In this sense, the most likely candidates for a large mispricing are small firms and distressed firms because companies in these two categories are known to have more binding credit constraints.

These considerations are relevant when constructing an index of pension plan funding level. In particular, the arguments in the previous paragraph suggest that the appropriate variable for scaling the dollar amount of pension liability is market value. Market capitalization is correlated with a firm's future cash flows, information diffusion (for example, through analyst coverage), and credit constraints. For this reason, the measure of funding status that we choose is the difference between assets and liabilities in the pension plan, scaled by the firm's market capitalization. The main results in the paper are obtained using this sorting variable.

It is reassuring, however, to find evidence of mispricing also when the scaling variable in the index of funding status is total assets. The fact that the magnitudes are somewhat smaller with this alternative measure corroborates the view that scaling by market capitalization selects the most likely candidates for mispricing. In particular, we argue that some highly levered, and presumably financially distressed, firms drop out of the extreme portfolios if the scaling variable is total assets. 
In our view, the magnifying effect of credit constraints is stronger when market capitalization is in the denominator rather than total assets.

The rest of the paper is organized as follows. Section I draws the link between this work and previous literature. Section II defines and summarizes the pension plan variables that are relevant for our analysis. Section III documents the fact that the most underfunded firms earn lower raw returns, and have a discount in their risk-adjusted returns. Section IV provides support for our interpretation of the mispricing by looking at several measures of earnings surprises. Section $\mathrm{V}$ characterizes the firms in our portfolios on the basis of their operating and financial performance. Section VI verifies that the observed mispricing is not absorbed by other known asset pricing anomalies in a cross-sectional framework. Also, Section VI presents robustness checks in which similar evidence is obtained using an alternative measure of funding status, and the results are articulated by size groups. Finally, Section VII proposes some insight for regulators and draws the conclusions of this work.

\section{Relation to Previous Literature}

This paper relates to two main strands of the literature. On the one hand, there is the work concerned with asset pricing anomalies. On the other hand, our paper addresses the old issue of the efficient valuation of pension liabilities, which is relevant from the point of view of corporate finance, public finance, and macroeconomics.

In terms of asset pricing, we believe the mispricing we find is similar in nature to other anomalies explored in the literature, such as the post-earnings-announcement drift (PEAD), first reported in Ball and Brown (1968) and later corroborated by Bernard and Thomas (1990), and the accrual anomaly described by Sloan (1996) and more recently by Chan, Chan, Jegadeesh and Lakonishok (2004). In Bernard and Thomas' (1990) explanation of the PEAD, investors do not anticipate the fact that quarterly earnings are autocorrelated, so they are systematically surprised when high earnings in one quarter are followed by high earnings in the next quarters. Sloan (1996) documents a negative relation between accruals, the difference between earnings and cash flows, and future returns, and argues that the market does not anticipate the fact that the accrual component of earnings will revert.

These anomalies, like the one we document, seem to depend on the failure of investors to fully exploit publicly available information. In particular, there is information in a firm's financial 
statements that has implications for future earnings, but which is not impounded into prices until the impact on future earnings finally manifests. The component of the mispricing that we identify relates to the fact that the neglected information concerns a liability of the company, rather than the quality of current earnings. The explanation we propose for our result is in line with the observation in Chan, Chan, Jegadeesh, and Lakonishok (2004) that the market fixates on bottom-line earnings and neglects other relevant information, which in this case is pension plan funding.

The results in Chan, Jegadeesh, and Lakonishok (1996) and Hong, Lim, and Stein (2000) are also consistent with our findings. In connection with momentum, they suggest that the market slowly impounds earnings news into prices, with negative information taking even longer to spread in the market. Our evidence of persistently lower returns for severely underfunded firms also suggests that bad news, that is, pension plan underfunding, takes more time to be fully incorporated into prices.

A final issue regarding asset pricing is that the results obtained in this paper are also relevant to the debate on the value premium. In particular, underfunded companies display poor past operating performance and high book-to-market ratios. Unlike other value firms, however, they are overvalued rather than undervalued. The immediate implication is that the value premium can be magnified by excluding underfunded firms from the value portfolios. Also, it seems that the belief that firms with poor past performance are generally undervalued needs to be at least in part reconsidered.

In terms of the valuation of the pension liability, the evidence that we present in this paper seems to be in sharp contrast with the conclusions of earlier work (Feldstein and Seligman (1981), Feldstein and Morck (1983), Bulow, Morck and Summers (1987)). These studies conclude that the market takes into account pension liabilities when valuing a company, and that the valuation is correct.

Besides the fact that we use a much longer and more recent sample, there are other ways to interpret the difference between our results and those of these previous studies. The methodology of this earlier literature consists of regressing market value on its possible determinants, as suggested by either a Tobin's Q model or a discounted cash flow model. Among the determinants, these authors use the funding status of DB pension plans. Taking into account taxes and other issues, the theory suggests that a one-dollar increase in pension plan funding should increase the market value of the company by about one dollar. ${ }^{5}$ Since the hypothesis of a coefficient on pension plan funding equal to one cannot be rejected, these studies conclude that the market correctly evaluates 
the pension plan funding status. In fact, given the size of their standard errors, a coefficient smaller than one cannot be excluded either, and thus our evidence of overvaluation would not be rejected in the context of those studies. More generally, the approach followed by this literature does not allow one to draw inferences on the efficiency of market valuation because the omission and mismeasurement of relevant determinants of company value, as well as the endogeneity of the funding status, are bound to bias the coefficient on the funding status.

Our methodology, which is more typical of asset pricing studies, circumvents these issues as it investigates the determinants of expected returns, rather than of market value. In particular, to draw our inference of mispricing we rely on deviations of the measured average returns from the expected return predicted by a factor pricing model. Obviously, our conclusion of inefficient market valuation is contingent on having chosen the correct asset pricing model (joint hypothesis problem, Fama (1970)). However, we also provide evidence of significant market surprises around earnings announcements. As argued by Fama (1991), given the short window around which returns are measured in an event study, the asset pricing model chosen as a benchmark is less relevant, and we can get as close as possible to a pure test of the efficient market hypothesis.

\section{The Pension Plan Data}

\section{A. Variable Definitions}

We obtain the accounting items related to defined benefit (DB) pension plans from Compustat. The variables of interest correspond to different accounting items over the years, and are initially available in 1980. In particular, we use accounting data to construct the equivalent of two pension plan elements, namely the fair value of plan assets (FVPA) and the projected benefit obligation (PBO). In Statement of Financial Accounting Standards No. 87 (SFAS 87) these two items are defined as follows:

- The FVPA represents the market value of the assets (stocks, bonds, and other investments) that are set aside and restricted (usually in a trust) to pay benefits when due. Plan assets include amounts contributed by the employer plus amounts earned from investing the contributions, less benefits paid.

- The PBO represents the actuarial present value of vested and nonvested benefits earned by an employee for service rendered to date plus projected benefits attributable to salary increases. 
The amount of benefits is determined by the plan's pension benefit formula, which establishes the payments that participants are entitled to receive. The measurement of the accumulated benefit obligation is based on current and past compensation levels. To compute the PBO the company makes an assumption on the expected increase in salaries for the employees covered by the plan, and computes the benefits that result from the salary increase using the benefit formula.

For accounting purposes, and in the rest of the paper, a pension plan is defined to be overfunded (underfunded) if the FVPA is larger (smaller) than the PBO. A company can sponsor both overfunded and underfunded pension plans. In the Appendix, we describe in detail the construction of the FVPA and PBO series from the available accounting items. The two series range from 1980 to 2002.

The definition of the variable we use to capture a firm's funding status deserves a separate discussion. We are interested in the eventual impact of the funding level of the pension plan on firm value through its impact on earnings and cash flows. Obviously, the same dollar amount of underfunding has different implications for these variables depending on the size of the company. Therefore, the difference between the FVPA and the PBO needs to be appropriately normalized. Given the discussion in the introduction, there are several reasons to expect that the mispricing that originates from underfunding is magnified by a factor that is inversely related to size. Hence, we choose to divide the difference between the FVPA and the PBO by market capitalization in December of the calendar year in which the pension items are measured, and we denote this variable as the funding ratio $(F R)$. The variable $F R$ is then defined as

$$
F R=\frac{F V P A-P B O}{M k t C a p} .
$$

A relevant criticism to normalization by market value is that this ratio could capture effects that are related to the company's book-to-market $(\mathrm{B} / \mathrm{M})$ ratio. In particular, for companies with positive $F R$, a higher level of $F R$ could correspond to a higher B/M ratio, without necessarily implying a better funding status. ${ }^{6}$ So, companies with high (and positive) $F R$ could earn high returns just because they are value firms. This argument is similar in spirit to the point made by Berk (1995), who suggests that using a price multiple as a sorting variable mechanically induces a relation with expected returns, and therefore with average returns.

As will be evident further on, by focusing on underfunded firms, our research design effectively circumvents this problem. By an argument similar to the one just above, a very negative $F R$ could 
hide a high $\mathrm{B} / \mathrm{M}$ ratio. Accordingly, a stock with very low and negative $F R$ should earn high returns, as it signals a value company. Given that we find that highly underfunded companies earn low returns, the value effect is not possibly what drives our results.

An alternative research design would be to normalize the same numerator by an accounting variable such as total assets or book value. In Section VI, we present results that use total assets as the denominator. Scaling by total assets removes from the most underfunded portfolio those companies that are most likely to be mispriced. This argument is discussed in more detail in Section VI.

\section{B. Overview of Pension Plan Elements}

It is interesting to look at the historical evolution of pension plan funding for companies with DB plans. Figure 1 reports the time series of the aggregate funding level for all the companies in Compustat with available pension items. The funding level is the difference between aggregate assets and PBO. As is evident from Figure 1, the DB pension system displays an aggregate underfunding for the first time in our sample in the years between 1993 and 1995. Concurrent with the bull market of the second half of the 1990s, pension plan assets grew more than benefits, peaked in 2000 at almost $\$ 1.8$ trillion. The contemporaneous slight decrease in aggregate benefits caused the aggregate funding level to peak in fiscal year 1999 with an aggregate overfunding of about $\$ 262$ billion. In the years between 2000 and 2002, the decline in the stock market caused a $20 \%$ fall in the value of pension plan assets, which culminated in fiscal year 2002 in an aggregate underfunding of almost $\$ 380$ billion. This astonishing deficit in DB pension plans is at the root of the concerns about the health of the DB pension system among analysts and regulators.

For the purpose of our asset pricing tests, we use accounting data up to the year 2002. The FIGURE 1 HERE companies included in our empirical analysis have to satisfy a number of selection criteria. The criteria that we discuss in this section are common to all types of analysis that we perform in the paper. From the Center for Research on Security Prices (CRSP) monthly data set we select only NYSE, Amex, and NASDAQ firms with ordinary common equity. Therefore, we exclude ADRs, REITs, and units of beneficial interest. Moreover, to correct for the survival bias induced by the way Compustat adds firms to its tapes (Banz and Breen (1986)), we do not include companies until they have at least two years of accounting data. We also restrict our analysis to companies that sponsor DB pension plans, which we identify as having available data for the pension accounting items that we describe above. Finally, to correct for the effect of outliers, we drop observations for 
each year in which the $F R$ variable is more than five standard deviations away from the annual mean.

There are 36,651 company-years in the sample between 1980 and 2002 that result from the intersection of these requirements. The year with the minimum (maximum) number of firms is 2001 (1981) with 1,213 (1,883) companies. Table I presents summary statistics on the main pension items and the $F R$ for these companies.

The average PBO in the whole sample is about $\$ 440$ million, which corresponds to about $91 \%$ TABLE I of the FVPA in the same period. The average funding level, as measured by $F R$, is about $1 \%$, the same as the median. This figure results from combining highly overfunded and highly underfunded companies. The minimum $F R$ is $-987 \%$, while the maximum is $572 \%$. The performance of the stock market affects the evolution of the funding status of companies with a DB pension plan as, on average, about $60 \%$ of the plan assets are invested in stocks. ${ }^{7}$ The funding status has been deteriorating over time, as liabilities have grown at a faster pace than assets. The average assets in a plan grew by about 2.7 times in the 1991 to 2002 sample relative to the previous decade, while the average pension obligation grew more than proportionally (2.96 times). This evolution caused the average $F R$ to drop from $2 \%$ to $-1 \%$.

\section{Portfolio Analysis}

In this section we sort firms into portfolios according to the level of $F R$. We form eleven portfolios. The first ten portfolios contain only underfunded firms $(F R<0)$ in a given year, while the eleventh portfolio is composed of all overfunded firms $(F R \geq 0)$, which we include in the analysis as a benchmark and for completeness.

Notice that because our main focus is on companies with negative $F R$, we avoid the problem mentioned in Section II concerning the possible relation between the level of $F R$ and the discount rate applied to the cash flows of these firms. Given that market value is the denominator, companies with very low and negative $F R$ are more likely to have high expected returns. Hence, our finding of low returns for highly underfunded companies is not likely to be explained by a mechanical relation between $F R$ and the discount rate.

We examine the performance of these portfolios at different horizons after portfolio formation by looking at raw returns. We also provide evidence on the risk-adjusted returns of these trading strategies. 


\section{A. Portfolio Formation Procedure}

Besides the criteria mentioned in Section II, the companies that we include in the portfolios have to satisfy an additional selection criterion. To be included in the portfolio formed in year $t$ a firm must have a nonmissing value for $F R$ in the fiscal year ending in year $t-1$ (which implies a nonmissing price in December of year $t-1)$.

In July of year $t$ the selected companies are allocated to one of eleven groups according to their $F R$ in December of year $t-1$. The first ten groups are formed using the deciles of the distribution of $F R$ for underfunded firms $(F R<0)$, while the eleventh group includes all the overfunded firms $(F R \geq 0)$. In more detail, to form the first ten groups, we use the break points of the $F R$ distribution of NYSE firms with negative FR. We use NYSE break points, as in Fama and French (1993), in order to avoid lower decile portfolios being entirely populated by smaller NASDAQ companies. The first portfolio contains the most underfunded firms, the tenth portfolio contains the least underfunded firms, and the eleventh portfolio, which we denote OF, contains all the overfunded firms.

We create the monthly portfolio return series by value-weighting or equally weighting the returns of the companies in each group from July of year $t$ to June of year $t+1$. Choosing July of year $t$ as the portfolio formation date ensures that the accounting information for the fiscal year ending in year $t-1$ is available to the market (Fama and French (1993)). If a company is delisted for performance reasons, the delisting return is used if available, and then the company is dropped from the portfolio. As mentioned above, companies for which $F R$ is more than five standard deviations from the annual mean are not included in the portfolios. Portfolios are reformed annually. The available monthly portfolio returns range from July 1981 to December 2003.

Table II reports descriptive statistics on the composition of the eleven portfolios and their returns. A thorough characterization of these companies in terms of their past earnings and other measures of performance is provided in Section V. The characteristics in Panel A are measured in December of $t-1$ relative to portfolio formation. There is wide dispersion in the average level of $F R$ across portfolios. For the most underfunded firms (portfolio one) the average $F R$ is about $-46 \%$, while for the least underfunded ones (portfolio ten) it is only about $-0.1 \%$. This portfolio therefore includes firms for which the underfunding is effectively very small. The OF portfolio includes all overfunded firms, and the average level of $F R$ is $6 \%$. The average size of the companies in the first

ten portfolios increases almost uniformly. The opposite is true for $\mathrm{B} / \mathrm{M}$, as most value firms are in portfolio one. This observation is relevant in contrasting our findings with the value premium. 
Notice, finally, that the OF portfolio contains on average a much higher number of firms than the other portfolios.

Panel B of Table II reports means and standard deviations for the returns of both valueweighted (VW) and equally weighted (EW) portfolios for the 270 months between July 1981 and December 2003. In anticipation of the main finding of this paper, we observe that the portfolio of the most underfunded firms has the lowest average monthly returns, in spite of the highest standard deviation, both in the VW and EW case. Notice that the low standard deviation of the $\mathrm{OF}$ is possibly related to the high number of firms in the portfolio, which provides a high degree of diversification.

Finally, Panel $\mathrm{C}$ of Table II provides means and standard deviations for the factors used in the time-series regressions. ${ }^{8}$ The EXM, HML, and SMB factors are constructed as in Fama and French (1993), and are respectively the market portfolio minus the risk-free rate, a portfolio long in high $\mathrm{B} / \mathrm{M}$ and short in low $\mathrm{B} / \mathrm{M}$ firms, and a portfolio long in small and short in large companies. The momentum factor (UMD) is constructed as a long investment in past twelve-month winners and a short investment in past twelve-month losers; its inclusion is justified by the evidence in Jegadeesh and Titman (1993) that past winners continue to gain extra returns over past losers within a one-year horizon.

\section{B. Raw Returns}

Table III reports compound returns at different horizons for both VW (Panel A) and EW (Panel B) portfolios. By looking at Panel A, we notice that in the first semester after formation (S1), portfolio one earns a negative return of about $-0.55 \%$. The difference in returns between portfolio one and the OF portfolio in this period is about $5.77 \%$. The fact that the average return for the portfolio of the most underfunded companies is negative suggests that the cause of its low returns is probably related to mispricing; this impression is strengthened by the evidence of market surprises in Section IV. Over the same six-month horizon, portfolios two and three also earn low returns compared to the rest of the universe of stocks. Overall, there is nonmonotonicity in average returns with respect to portfolio ordering, which clearly indicates that only extreme levels of underfunding produce returns that are significantly lower.

TABLE III

In the first year after portfolio formation (Y1), the difference in compound returns between the HERE OF portfolio and portfolio one decreases to $4.58 \%$. Evidently, most of the return difference in year one is produced in the first six months. Portfolio two still earns lower returns, but for this portfolio 
the difference in returns compared to the rest of the stocks tends to vanish with time. Instead, the striking result is that the first portfolio continues to earn comparatively low returns even five years after portfolio formation. This result acquires even more relevance when considering that firms in portfolio one are small and value companies and as such should earn high average returns.

The situation for EW portfolios in Panel B is consistent with the evidence in Panel A. The main difference is that portfolio one returns in the first six months are even smaller $(-4.02 \%)$ and that portfolio two also earns negative returns $(-1.50 \%)$ over the same horizon. These results suggest that underfunding is associated with comparatively lower returns in the case of smaller firms, at least in the early period after portfolio formation.

Overall, the evidence from raw returns is consistent with the mispricing view that we propose in the introduction. In particular, the negative returns in the first period after portfolio formation suggest that investors are surprised by negative information. This impression is confirmed by the analysis of returns around earnings announcements in Section IV. Furthermore, the fact that low returns for the portfolio of mostly underfunded firms persist even five years after formation is also consistent with our interpretation. As we mention in the introduction, ERISA imposes on severely underfunded firms the obligation to contribute over a three- to five-year period. This implies that the surprises will not materialize in a single moment, but rather will be spread over several periods as amortizations and contributions affect earnings and cash flows. This gradual adjustment of returns to pension funding information is also possible due to the persistence in underfunding: if the underfunding was short lived or exhibited fast reversals then the sequence of surprises would not materialize. ${ }^{9}$

\section{Risk-Adjusted Returns}

We point out above that underfunded companies, on average small and value companies, should have high expected returns. Therefore, the evidence of low returns for the low $F R$ portfolios is not likely to be explained by risk factors related to size or B/M. However, one can formally test that these portfolios earn low risk-adjusted returns by running time-series regressions of portfolio returns on the returns on different factors, including the market. A priori a difference in returns among the portfolios could be explained by different factor loadings.

Table IV reports alphas, factor loadings, and $\mathrm{R}^{2}$ of the time-series regressions

$$
R_{i t}=\alpha_{i}+b_{i} E X M_{t}+h_{i} H M L_{t}+s_{i} S M B_{t}+\varepsilon_{i t},
$$

where $R_{i t}$ is the portfolio excess return. The estimation sample is July 1981 to December 2003. 
From Panel A we infer that returns are significantly negative once we control for the effect of known factors. Portfolios one and two have significantly negative intercepts, both in the VW and EW cases. For example, the VW portfolio one has a significantly negative alpha of $-0.89 \%$ monthly, which amounts to about $10.6 \%$ annually. Consistent with the results for raw returns, there seems to be no clear pattern in the alphas beyond the first two portfolios. Notice in particular that the alpha of the OF portfolio is not very far from zero. This result persists also when highly overfunded companies (top decile) are isolated in a portfolio (results not reported). This evidence suggests that the effect of the funding status is not symmetric between under- and overfunded firms. A possible explanation for this asymmetry is provided by short-termism, which causes managers to anticipate the gains from a surplus in the pension plan.

Panel B shows that the most underfunded portfolios not only have higher loadings on HML and SMB, as one would expect given their size and B/M, but they also have higher market betas. Consequently, adjusting for risk increases the wedge between the returns of the most underfunded companies and most overfunded.

Another known pattern in returns is momentum. There is evidence that past winners tend to outperform past losers in the following year (Jegadeesh and Titman (1993)). In Section V, we present evidence that the most underfunded companies tend to have poor past operational performance. A reasonable concern is that the underperformance of the most underfunded companies can be driven by momentum. There are a number of ways to address this concern. A first reply is that momentum is a short-lived phenomenon (Chan, Jegadeesh, and Lakonishok (1996)), whereas we have shown that the underperformance of severely underfunded companies is long-lasting (at least up to five years after portfolio formation). Later, in Section VI, we also control for different types of momentum in a cross-sectional setting, and show that the explanatory power of $F R$ survives. Here, we include a momentum factor in the time-series regressions by estimating the model

$$
R_{i t}=\alpha_{i}+b_{i} E X M_{t}+h_{i} H M L_{t}+s_{i} S M B_{t}+m_{i} U M D_{t}+\varepsilon_{i t}
$$

Table $\mathrm{V}$ reports alphas, factor loadings, and $\mathrm{R}^{2}$ for the four-factor model in Equation (3). Although the momentum factor can account for a fraction of the alphas, Panel A shows that the mispricing of the most underfunded portfolios is still large. In particular, the VW portfolio one still has a very negative alpha $(-0.76 \%)$, which is significant at the $5 \%$ level. Momentum seems to have a larger impact on EW portfolios, as the alpha of portfolio one drops to $-0.35 \%$. This fact is consistent with the evidence that momentum is more relevant among smaller companies (Hong, Lim, and Stein (2001)).

TABLE V HERE. 
Panel B of Table V shows that the most underfunded companies have negative UMD loadings, suggesting that these stocks behave like momentum losers. This finding is not surprising, especially in light of the evidence presented below (see Section V, and Panel A of Table VII), which shows that the most underfunded companies have the lowest returns in the year before portfolio formation. Given the already mentioned persistence in the degree of underfunding, it is possible that the negative surprises, which cause the observed negative returns for underfunded firms, occur repeatedly for a few years in a row. This fact is partly captured by a negative correlation with the momentum factor, but has a foundation in the negative impact on earnings of the pension liability. Overall, the evidence in Table V, together with the results we present later, suggests that the mispricing identified by the funding level is in large part of a different nature than momentum.

A recent paper by Pastor and Stambaugh (2003) points out that stocks with high loadings on an aggregate liquidity factor earn significantly higher abnormal returns than stocks with low liquidity betas. These authors argue that this extra-return remunerates investors for the risk of holding assets that have low returns, and possibly require liquidation, in periods when market liquidity is low. We want to investigate the possibility that the mispricing of our $F R$ portfolios is related to the liquidity risk pointed out by Pastor and Stambaugh. We re-estimate the asset pricing models in Tables IV and V including Pastor and Stambaugh's spread portfolio, which is constructed as the return on high liquidity beta stocks minus the return on low liquidity beta stocks. The results, which we do not report to save space, indicate that the mispricing of our portfolios is only slightly affected by the inclusion of the liquidity factor. The portfolio of most underfunded firms has a significantly negative loading on the new factor, and its alpha is reduced by about $30 \%$ when this factor is included in the model, but it remains significant. The highest $F R$ portfolios have positive and insignificant loadings, while OF loads negatively on the liquidity factor. Overall, this evidence indicates that a large part of the returns of severely underfunded firms is not explained by Pastor and Stambaugh's (2003) liquidity risk.

To summarize, the evidence presented in this section suggests that the most underfunded companies have persistently lower returns than companies that have a healthy funding status in their pension plan. The difference in returns is not explained by market risk, B/M, size, or momentum. The next step is to provide evidence of market surprises for the portfolios of most underfunded firms. 


\section{Evidence of Market Surprises}

The economic story that we believe to be behind the observed overvaluation of severely underfunded companies is spelled out in the introduction. Here, we summarize the testable implication of this argument.

For a number of reasons that are partly related to operating performance, and which we consider as exogenous to this discussion, firms develop either a deficit or a surplus in their pension plan. If managers are to some extent driven by short-term considerations, they have an incentive to immediately recognize the pension plan surplus in the income statement of the fiscal year in which it materializes. On the other hand, there is an incentive to postpone the recognition of a loss in the pension liability. Nonetheless, if the loss is very large (above $10 \%$ of the maximum between PBO and FVPA), the firm is obliged to amortize it in the fiscal year following the one in which it materializes. The amortization of the pension loss and the contributions to the pension plan decrease earnings and cash flows of severely underfunded companies in the year following the first occurrence of the large underfunding.

We hypothesize that the reason why severely underfunded firms experience abnormally low returns is that the market is surprised when the implications of the pension underfunding hit earnings and cash flows. That is, while the market pays attention to earnings and cash flow figures when valuing companies, it does not pay enough attention to pension liabilities.

It is beyond the scope of this paper to explore the causes of this myopic focus on earnings. Suffice it to say that there is a consensus in the finance literature about the fact that investors pay a disproportionate attention to earnings relative to the other items in a company's financial statements. For example, Chan, Chan, Jegadeesh, and Lakonishok (2004) argue that the almost exclusive focus on bottom-line earnings is at the basis of the so-called accrual anomaly (Sloan (1996)).

For our purpose, the relevant implication of this story is that the market surprise should be observable around earnings announcements. If earnings in the year following the appearance of the pension liability are lower than expected by investors, then severely underfunded firms should have predictably negative price surprises around earnings announcements. To test this implication, we compute price reactions around earnings announcements in two ways. One measure is simply the cumulative stock returns in the three days around the announcement (from $t-1$ to $t+1$ ). For 
stock $i$ in period $t$ the cumulative return around the announcement is

$$
C R_{i t}=\sum_{j=-1}^{+1} r_{i j}
$$

where $r_{i j}$ is stock $i$ 's return on day $j$ (with earnings being announced on day 0 ). We average $C R_{i t}$ across the stocks in the portfolio over the period under consideration (either a quarter or a year). This measure is unadjusted for risk. The other measure is also a cumulative stock return in the same three-day window, but the daily stock returns are adjusted for risk using the daily returns on the three Fama and French (1993) factors. For stock $i$ in period $t$ the adjusted cumulative return around the announcement is

$$
A C R_{i t}=\sum_{j=-1}^{+1}\left(r_{i j}-b_{i} E X M_{j}-h_{i} H M L_{j}-s_{i} S M L_{j}\right),
$$

where $E X M_{j}, H M L_{j}$, and $S M L_{j}$ are the day-j $j^{t h}$ returns on the three factors. We impute to each stock the factor loadings $\left(b_{i}, h_{i}\right.$, and $\left.s_{i}\right)$ of the $F R$ portfolio to which it belongs during the formation period. These loadings are estimated using the full sample of portfolio returns and are the ones reported in Panel B of Table IV. The adjustment is meant to take care of the fact that the most underfunded companies have high loadings on the market, HML, and SMB, and as such they earn high expected returns, which could conceal the negative surprise. Again, the stock returns around the announcements are averaged across stocks in the portfolio over the period of interest.

The second implication is that, if one forms expectations of future earnings based on past earnings only, there should be negative surprises associated with the most underfunded firms. Consequently, a consistent measure of earnings surprise is the commonly used standardized unexpected earnings (SUE). Following Chan, Jegadeesh, and Lakonishok (1996), the assumed model for expected earnings is a seasonal random walk, and the SUE for stock $i$ in quarter $t$ is thus

$$
S U E_{i t}=\frac{e_{i t}-e_{i t-4}}{\sigma_{i t}}
$$

where $e_{i t}$ is quarterly earnings in quarter $t, e_{i t-4}$ is quarterly earnings four quarters before, and $\sigma_{i t}$ is the standard deviation of unexpected earnings, $e_{i t}-e_{i t-4}$, over the preceding eight quarters. The firm SUE are averaged across companies in the portfolio over the period of interest.

The third measure of earnings surprise is given by the revision in analysts' forecasts of earnings. If the implications of the pension liability are not taken into account, analysts should revise downward their forecasts of future earnings of the most underfunded firms as the earnings release 
date approaches, and this revision should be larger than for the other companies. As in Chan, Jegadeesh, and Lakonishok (1996), we define the revision in month $t$ for stock $i$ as the change in earnings forecasts by analysts scaled by the prior month's stock price, that is,

$$
R E V_{i t}=\frac{f_{i t}-f_{i t-1}}{p_{i t-1}}
$$

where $f_{i t}$ is the median $\mathrm{I} / \mathrm{B} / \mathrm{E} / \mathrm{S}$ estimate in month $t$ of firm's $i$ 's earnings for the current fiscal year, and $p_{i t-1}$ is the stock price in month $t-1 .^{10}$ The revisions are averaged across stocks in a given month and then summed over the period of interest.

Each measure of surprise has some advantage over the others. For example, SUE capture expectations over a longer period than the other two measures, however, the expectations in SUE are based on the assumption of a specific model for earnings. Analysts' revisions, meanwhile, could be driven by the incentive to generate brokerage commissions or investment banking fees. Therefore, it is worthwhile to consider the different indicators simultaneously.

Panel A of Table VI reports the portfolio cumulative returns around earnings announcements. The most striking result is that in the first quarter after portfolio formation both portfolio one and two have negative price reactions. This finding represents strong evidence of the market being negatively surprised by earnings announcements, especially if one considers that the other portfolios earn positive returns during the same period. For portfolio one the negative return persists one year after formation, and in this case the difference in returns with the OF portfolio is statistically different from zero. In general, the most underfunded stocks continue to have the lowest returns around earnings announcements up to five years after portfolio formation, consistent with the results using raw returns in Table III.

Panel B of Table VI reports risk-adjusted returns around earnings announcements and reinforces TABLE VI the impression from Panel A. Here, the difference in returns between portfolios one and OF is significant in quarter one, in year one, and in year five after portfolio formation. Besides, in all the periods that are considered, the portfolio of the most underfunded companies has negative risk-adjusted returns around earnings announcements. Evidently, correcting for risk accounts for the fact that these companies are small and value firms with high market betas.

Moving to the SUE evidence in Panel C of Table VI, we find further support for the negative surprise hypothesis. The SUE for portfolios one and two are consistently the lowest in every period that we consider after portfolio formation. Moreover, they are negative in the first quarter and the first year after formation. The difference between the SUE of portfolio one and OF is significantly 
different from zero in all periods under consideration. Furthermore, in year five after formation, portfolio one still displays negative SUE.

Finally, Panel D of Table VI reports results using the revisions in analysts' forecasts. Consistent with prior evidence (Chan, Jegadeesh, and Lakonishok (1996)) the average revision is negative across the board, suggesting that analysts tend to be over optimistic about earnings. The relevant point is that the portfolio with the most underfunded firms displays the largest negative revision in all periods, and the difference in revisions with the OF portfolio is most of the time significantly different from zero. Remarkably, the result in year five is still consistent with a long-lasting effect of underfunding on earnings and returns.

In conclusion, we believe the results on the persistence of the predictive power of $F R$ corroborate the conjecture that we elaborate in the introduction. In particular, given that ERISA forces the employer to fund highly underfunded pension obligations within three to five years, these compulsory contributions can represent another source of surprise a few years down the road.

\section{Portfolio Characteristics}

Lakonishok, Shleifer, and Vishny (1994) argue that the value premium and the growth discount are explained by overreaction to past operating performance. In that context, value companies with a long history of poor earnings tend to be undervalued. On the other hand, Chan, Jegadeesh, and Lakonishok (1996) show that firms with negative past operating performance continue to earn low returns within a six-month horizon. They suggest that return momentum (Jegadeesh and Titman (1993)) is at least partly due to underreaction to news contained in earnings. Furthermore, there is evidence that the market does not understand that the part of earnings due to accruals tends to reverse itself. Hence, high accruals are associated with low future returns (Sloan (1996), Chan, Chan, Jegadeesh and Lakonishok (2004)). Given these results, in order to compare the mispricing that this paper identifies to previous anomalies, it is important to provide a description of the companies in the $F R$ portfolios in terms of their operating performance and other defining characteristics. Also, looking at operating performance can indicate why these firms developed a pension liability.

First of all, we recall that according to Table II the most underfunded companies have the smallest size and highest $\mathrm{B} / \mathrm{M}$ ratio in the universe of DB companies that we consider. Moreover, separate results confirm that these characteristics persist at least up to five years before and after 
portfolio formation. Therefore, we can confidently describe the most underfunded firms as being relatively small and value.

Table VII, Panel A reports average portfolio returns in different periods before portfolio formation. The goal, here, is to see whether the momentum anomaly can be related to the low returns of underfunded companies. Indeed, we observe that in the three years before formation, the portfolio of most underfunded companies earns the lowest returns. However, the striking finding is that in the six months prior to formation the same portfolio earns the highest returns. As momentum is a short-run phenomenon, this finding makes it unlikely that price momentum explains the low returns of the underfunded portfolios after formation. This impression is confirmed by the cross-sectional analysis in Section VI.

The finding that the most underfunded companies earn the highest returns in the six months before formation (January to June) has to be interpreted in conjunction with the evidence that their TABLE returns are lowest between July and December of year $t-1$. For example, portfolio one's return is about $-12.4 \%$ between July and December of year $t-1$. We can think of two possible interpretations of this evidence. First, it could be the case that at the end of year $t-1$ investors start reacting to the negative operating performance of severely underfunded companies (see Panels D to F of Table VII). Then, possibly because of overreaction to poor earnings (Lakonishok, Shleifer, and Vishny (1994)), there is a correction of the initial negative surprise in the months between January and June. The extent of this positive rebound is proportional to the magnitude of the initial negative reaction. The second possible explanation has to do with tax-loss selling in December of year $t-1$. Since the most underfunded companies are losers from the point of view of returns, they are the most likely candidates for tax-loss selling by investors who seek to offset capital gains from other stocks in their portfolios. In this view, the rebound in prices during the first months of year $t$ occurs because investors repurchase the stocks that they had sold in December of year $t-1$.

Panel B of Table VII provides average portfolio SUE in different periods before formation. The purpose is to see whether there is a relation with earnings momentum. In general, the first two $F R$ portfolios have negative SUE, consistent with deteriorating operating performance. However, the second $F R$ portfolio in the first six months before formation does not have negative SUE, in spite of poor returns after formation. This fact, along with the robustness checks in the cross-sectional analysis of Section VI and the persistence of low returns several years after formation, works against earnings momentum as the sole explanation for the findings of this paper.

Panel C of Table VII clearly testifies to the lack of a relation between the low returns of 
underfunded companies and the accrual anomaly. The most underfunded companies have the lowest accruals both before and after portfolio formation. Given that low accruals are normally associated with high returns, it is unlikely that this anomaly explains the abnormally low returns of severely underfunded companies. The cross-sectional analysis below confirms this conclusion.

The rest of Table VII looks directly at operating and financial performance. Panel D and Panel E consider the ratios of earnings and cash flows to total assets in different periods before and after portfolio formation. The choice of presenting scaled levels of earnings and cash flows is imposed by the fact that it is not possible to compute growth rates for these variables, as in some years they are negative, even at the portfolio level. From these two panels it appears that the two most underfunded portfolios tend to have the poorest operating performance before and after formation. Furthermore, both earnings and cash flows ratios are lower in the first year after formation for portfolios one and two, while this is not necessarily the case for the other portfolios.

This evidence is instructive for several reasons. First, poor past performance can be the reason why these firms do not fund their pension liability in a timely manner and thereby develop a large underfunding. Second, the fact that the operating performance worsens in the first year after formation is consistent with the pension liability negatively impacting earnings and cash flows, and corroborates our explanation of the observed low returns for underfunded companies.

Panel F of Table VII provides the growth rate of total sales for the companies in the portfolios. Consistent with deteriorating earnings and cash flows, the sales growth rate for the most underfunded companies is lowest in the periods before portfolio formation. Since the sales figure is less subject to managers' manipulation, this result is more convincing about the poor operating performance of severely underfunded firms than the results concerning earnings and cash flows.

An important piece of evidence in Panel F concerns the periods after portfolio formation, when the growth rates of sales for the most underfunded portfolios are not lower than those of the other portfolios. This finding suggests that the reasons for the poor performance of earnings and cash flows are not necessarily found in normal operations. Instead, it supports the view that the poor performance after portfolio formation is due to the amortization of the pension liability and the contributions to the pension plan.

Finally, the last two panels of Table VII report two different measures of company distress. In Panel G there is Ohlson's (1980) index of bankruptcy risk. A higher level of this index denotes higher probability of default. Panel H reports Altman's (1968) Z-score, which is inversely related to bankruptcy risk. ${ }^{11}$ Both measures show that the portfolios of highly underfunded firms have the 
highest probability of default in all periods under consideration. Therefore, these companies can be noted as relatively distressed both before and after portfolio formation.

The observation that severely underfunded companies are companies facing financial trouble is interesting for two reasons. First, it sheds further light on why these firms develop a large unfunded pension liability. Possibly, they fund their other obligations by expanding the pension liability. Second, it suggests that distress may play an amplifying role on the impact of pension contributions on company value. We discuss this issue in detail in Section VI, when we consider alternative measures of underfunding.

In conclusion, the analysis of the characteristics of underfunded companies identifies the anomaly presented in this paper as largely independent of previous findings. Severely underfunded companies are firms with poor past operating performance and in relative financial distress. These characteristics make them similar to value companies. Unlike standard value companies, however, underfunded firms earn low returns. Furthermore, the poor operating performance would suggest a connection with earnings momentum. Nonetheless, prior six-month returns do not identify the most underfunded companies as losers. Also, unlike price momentum, which is a short run phenomenon, a high level of underfunding is associated with low returns up to five years after portfolio formation. Finally, the level of accruals would suggest that underfunded companies should earn higher returns than the rest of the sample, which is in contrast with the evidence. These issues are further investigated in the next section.

\section{Robustness Analysis}

\section{A. Cross-Sectional Regressions}

A way to statistically test whether the predictive power of $F R$ for returns survives when controlling

for the effect of other known sources of predictability is provided by the cross-sectional methodology of Fama and MacBeth (1973). Following this approach, we use market beta, size, B/M, past sixmonth returns, SUE, and accruals as explanatory variables in cross-sectional regressions along with FR.

As we mention in Section II, in the case of stocks with positive $F R$, there could be a mechanical correlation between $F R$ and the B/M ratio. Thus, a positive association between $F R$ and returns could be a manifestation of the value premium. Even controlling for B/M in the regressions does not solve the problem, as there could be nonlinearities in the value effect. To circumvent this obstacle, 
we let $F R$ vary only for underfunded companies and replace the value of $F R$ for overfunded firms with zero. Furthermore, we create a dummy variable called $F R(+)$ which is equal to one if the company is overfunded. This dummy captures the premium in average returns on overfunded companies relative to underfunded ones. In regressions of returns on the new $F R$ and $F R(+)$, the estimated slope on $F R$ is numerically equivalent to the slope from a regression in which the original $F R$ is the only explanatory variable and where overfunded companies are dropped from the sample. When other explanatory variables are included in the regression, this equivalence does not hold and a larger number of observations enhances the statistical power of the tests. For this reason, we prefer to keep overfunded companies in the sample.

Another possibility to get around the mechanical correlation between $F R$ and B/M is to define the funding ratio in a different way. A possible alternative is to divide the difference between assets and liabilities in the pension plan by total assets. Hence, we define the variable $F R^{\prime}$ as

$$
F R^{\prime}=\frac{F V P A-P B O}{\text { Total Assets }}
$$

Given that this new variable is not related to B/M, we can let it vary freely for both under- and overfunded companies, without running the risk of capturing effects related to the value premium. Moreover, $F R^{\prime}$ provides a robustness check for the results obtained with $F R$.

As for the other explanatory variables, we use a firm's market equity at the end of December of year $t-1$ to compute its B/M ratio. ${ }^{12}$ Market equity in June of year $t$ measures firm's size. Accruals are computed as in Sloan (1996) using data from fiscal year $t-1$. The (log of the) size, (the log of) B/M, FR, and accruals of a company are associated with the stock returns between July of year $t$ and June of year $t+1$. Each month a firm is associated with its SUE in the most recent quarter and with the compounded return in the prior six months $\left(R_{-6}\right) .{ }^{13}{ }^{14}$ We also need to provide an estimate of the market beta for each company. For this purpose, we follow closely the spirit of Fama and French's analysis (1992). We impute to each company the beta of the portfolio to which it belongs among the portfolios formed according to the deciles of the beta distribution. The details of this procedure are in the Appendix.

We run a cross-sectional regression for each month in the sample. The dependent variables in the regression for month $t$ are stock returns between months $t$ and $t+6$. The slopes are computed as the time-series average of the monthly slopes. Given that the regressions are run at the monthly frequency and the dependent variables are six-month returns, there is serial correlation in the estimated slopes. This fact is taken into account by adjusting the standard error of the mean with the Newey and West (1987) procedure. The sample ranges from July 1981 to December 2003. 
Table VIII reports the results from the cross-sectional regressions. In Panel A, the funding ratio is measured using the combination of $F R$ and $F R(+) . F R^{\prime}$, which is defined with total assets in the denominator, measures funding status in Panel B.

The first two models in Panel A of Table VIII confirm known results in asset pricing. The failure of beta to explain the cross-section of stock returns, which was pointed out by Fama and TABLE French (1992), is very strong in our sample. The estimated relationship between beta and returns is negative and insignificant. There is a negative relation between size and returns, but it is not significantly different from zero. This result is consistent with the known evidence that the small firm effect disappeared starting in the 1980s. Finally, B/M is a significant predictor of average returns, confirming that the value effect still plays an important role.

The new evidence in Panel A of Table VIII concerns the models with $F R$ in the regression. The estimates in the third row show that $F R$ is a significantly positive predictor of stock returns, even accounting for beta, $\mathrm{B} / \mathrm{M}$, and size. The slope on the $F R(+)$ dummy suggests that overfunded companies as a group do not earn significantly different average returns, keeping the other regressors constant. This result is the cross-sectional counterpart to the lack of significant alphas for the OF portfolio in the time-series analysis. Also, it is further evidence of the asymmetric effect of the funding status on average returns, for which we provide a possible explanation above.

The next three models control separately for the effect of accruals, earnings momentum (SUE), and returns momentum $\left(\mathrm{R}_{-6}\right)$, respectively. Each of the variables is significant and has the expected sign. The most significant is SUE. What matters is that the predictive power of $F R$ is not altered by the separate inclusion of these regressors. Even when the control variables are included simultaneously in the last row of Table VIII, the funding ratio remains a significant determinant of stock returns and the slope is unaffected. Incidentally, notice that prior six-month returns are no longer significant, probably because the effect of this variable is subsumed by SUE. This fact suggests that in our sample return momentum is largely explained by earnings momentum, which is consistent with the results in Chan, Jegadeesh, and Lakonishok (1996).

Panel B reports the estimates obtained using $F R^{\prime}$, the alternative measure of funding status. The results are very similar to those in Panel A, both in terms magnitude of the slope on $F R^{\prime}$ and in terms of its significance. In addition, the slopes on the other explanatory variables are largely unaffected by the change in the measure of funding status. Hence, the significant relation between average returns and funding level seems to be robust to the definition of the funding ratio.

In summary, the evidence from the cross-sectional analysis confirms the significant relation 
between the funding status and average returns of underfunded companies. Also, it reinforces the impression from earlier sections that this phenomenon is largely independent of other known asset pricing regularities. Finally, the cross-sectional link is robust to alternative definitions of the funding status. ${ }^{15}$

\section{B. Analysis by Size Groups}

In the introduction, we suggest that analyst coverage, and the quantity and quality of information in general, can interact with underfunding in determining mispricing. Both financial constraints and analyst coverage are negatively correlated with size. A natural question is then whether a small size represents a necessary condition for mispricing. To answer this question, we look at the returns on underfunded firms in different size groups.

Firms are independently sorted by size and $F R$, and value-weighted portfolios are formed from the intersection of these two sorts. Five groups of underfunded firms are formed according to the quintiles of $F R$ in December of year $t-1$, conditioning on negative $F R$ values. Then, all overfunded $(\mathrm{OF})$ firms are grouped together. In addition, five groups are formed on the basis of market capitalization in June of year $t$, using the breakpoints of the distribution for NYSE stocks. The thirty portfolios are reformed in July of each year. Monthly portfolio returns range from July 1981 to December 2003.

Table IX reports alphas and factor loadings from time-series regressions of portfolio returns on the Fama and French (1993) three factors. The main evidence from the table is that the mispricing of underfunded firms is not just limited to the smallest firms. In fact, the most underfunded companies in all size quintiles display negative alphas. The largest mispricing is $-0.94 \%$, for the most underfunded portfolio in the third size quintile. This intercept slightly decreases to $-0.81 \%$ when the momentum factor is included (results not reported), and stays statistically significant. The lack of statistical significance of the estimated alphas for the largest portfolios of severely underfunded firms depends on the fact that they contain fewer stocks, and therefore bear more idiosyncratic risk. Furthermore, notice that within each size group the most underfunded portfolios have the highest loadings on the three factors, consistent with the findings in Section III.

TABLE

On the basis of this evidence, we conclude that small size is not a necessary condition to IX determine mispricing of underfunded firms. Rather, this condition, when it interacts with high HERE underfunding, can magnify the mispricing. 


\section{Conclusions}

In this article we examine the issue of the efficient market valuation of companies with a defined benefit pension plan and find significant evidence of overvaluation for firms with severely underfunded pension plans over the last two decades.

In particular, we show that the portfolio with the most underfunded firms earns low raw returns relative to portfolios of firms with healthier pension plans. This phenomenon persists for at least five years after the emergence of the large underfunding. Also, the risk-adjusted returns of this portfolio are significantly negative. The magnitude of the discount in returns is around $10 \%$ annually.

We interpret this evidence as being due to investors not paying enough attention to the implications of the current underfunding for future earnings and cash flows. The low returns we predict are, in our view, a consequence of the fact that investors are systematically surprised by the negative impact of the pension underfunding on earnings and cash flows. As the regulatory environment allows companies to postpone the recognition of the pension liability in earnings, the impact on returns occurs with delay relative to the first manifestation of the large underfunding.

Consistent with this interpretation, we provide significant evidence of market surprises in the period after portfolio formation. The surprises take the form of negative returns around earnings announcements, negative standardized unexpected earnings, and lower than average revisions in analysts' forecasts. Also, we document that earnings and cash flows deteriorate after portfolio formation.

The most underfunded firms tend to be past losers from the point of view of returns and operating and financial performance. This evidence suggests that the deficit in the pension plan must have emerged from a difficulty for these companies to satisfy the funding requirements, which in turn is a consequence of their poor economic performance and inability to borrow. Moreover, the largest discount in returns seems to be associated with higher leverage. We interpret this fact by arguing that for the most levered among the underfunded firms, the negative price adjustments at the time of earnings surprises are larger. Given the credit constraints that most of these firms face, cutting their cash flows to fund the pension plan causes them to give up to a larger number of value enhancing opportunities than what they would do if they could freely borrow.

Finally, through cross-sectional analysis and other descriptive evidence, we reach the conclusion that the overvaluation related to pension plan underfunding is independent of other asset pricing regularities such as the size effect, the value premium, return momentum, earnings momentum, and the accruals anomaly. Hence, we are inclined to believe that we have identified an additional 
layer of mispricing relative to the ones already known in the finance literature.

The anomaly that is documented in this work may have implications at both the corporate and the macroeconomic levels. We mention here just a few of these implications. First, managers of corporations may choose to behave strategically in the choice of capital structure at times when market equity valuations fail to reflect the value of pension assets and liabilities, as our evidence suggests. For instance, in the interest of old equity holders, managers of overvalued underfunded companies may choose to issue equity rather than debt when raising new capital. ${ }^{16}$ Second, this anomaly may generate inefficiencies in the allocation of resources, along the lines of the quotation from Bulow, Morck, and Summers (1987) cited in the introduction. Third, in terms of public finance, one may want to reassess the comparison between the U.S. pension system and other alternatives, such as the more public-oriented systems in continental Europe. All these elements seem sufficiently important to be addressed in future research.

In our view, the fact that the aggregate pension liability has reached the astonishing level of $\$ 380$ billion gives some urgency to the need for action on the regulators' side. For this reason, before concluding, we address a few policy recommendations. First, an important question that calls for a timely reply is how much of the outstanding liability is already reflected in stock prices. According to our interpretation of the mispricing, this issue should be addressed by assessing how advanced companies are in the amortization process of pension losses. If companies are lagging behind, then large price adjustments are still to be expected. Further, regulators should increase investor awareness of the implications of pension liabilities for company value. This informational activity would facilitate the correct market valuation of underfunded companies, and would prevent drastic price adjustments. In summary, we believe that any reform of the current accounting system should aim at allowing pension funding status to be reflected in a firm's income statement without delay or excessive discretion. This change may increase earnings and, perhaps, return volatility, but we believe the gains in terms of information diffusion would be substantial. Such a measure would also foster unequivocal interpretation of the impact on earnings and cash flows of a given level of underfunding, and therefore facilitate the efficient valuation of these companies. 


\section{Appendix}

\section{A. Accounting Data Definitions}

There are two structural breaks in the way Compustat reports pension related items. The first break coincides with the reform of accounting standards introduced by SFAS 87, which changes pension accounting effective for fiscal years beginning after December 15, 1986. The second break is caused by SFAS 132, which is effective for fiscal years beginning after December 15, 1997.

For companies with fiscal years ending between 1980 and December 1986, the FVPA is set equal to the content of item 245. For these years, we define the pension liability as equal to the present value of vested benefits (item 243). This definition differs slightly from the PBO, as it does not incorporate projected increases in salaries. Indeed, it corresponds to another measure of pension obligation called Accumulated Benefit Obligation (ABO).

Starting from 1987 for most companies, and before 1987 for those companies that report it, we define the FVPA as the sum of overfunded pension plan assets (item 287) and underfunded pension plan assets (item 296). One change introduced by SFAS 132 is that companies are not required to report separate items for over- and underfunded plans. Hence, for fiscal years beginning after December 1997, Compustat collapses the FVPA and the PBO into the corresponding item that was previously reserved for overfunded plans. After the introduction of SFAS 87 the PBO is reported by all companies with a DB plan (item 286 for overfunded plans, and item 294 for underfunded plans).

As we indicated above, before the introduction of SFAS 87 the available data allow us to construct a variable that is closer to the ABO than the PBO. Hence, the series is not entirely homogenous as our measure of the present value of future contributions corresponds to the present value of vested benefits (item 243) up to the introduction of SFAS 87, and to the PBO afterwards. Given that for the most part of this series the PBO is the relevant measure of pension liability, in the text we simply label this series PBO. Results by subsamples, and other results in which we replace the $\mathrm{PBO}$ with the $\mathrm{ABO}$ (available only up to 1997), show that the break in the definition

of the series does not seem to be crucial for the conclusions presented in the paper. All of these results are available from the authors upon request. 


\section{B. Betas in the Cross-Sectional Analysis}

Imputing to a company the estimate of beta resulting from the available time series of returns would cause too much measurement error because of the instability of company betas and the amount of idiosyncratic risk. To get around this problem, we adopt a two-step procedure. In the first step all firms in CRSP with ordinary common equity and returns between July 1976 and December 2003 are used to compute pre-ranking betas. A firm pre-ranking beta for year $t$ results from a market model in which the estimation window ends in June of year $t$ and begins at least 24 and at most 60 months before, depending on returns availability. Then, the pre-ranking betas are sorted to determine the deciles of the beta distribution and firms are assigned to decile portfolios accordingly. The portfolio returns are obtained by value-weighting the stock returns from July of year $t$ to June of year $t+1$. The sample of returns on beta-sorted portfolios goes from July 1981 to December 2003. In the second step, full sample (post-ranking) betas are computed for these portfolios, and each company is assigned the beta of the portfolio to which it belongs. This beta is used as an explanatory variable in the cross-sectional regression. It is important to notice that the post-ranking betas closely reproduce the ordering of the pre-ranking betas. They increase uniformly from 0.42 for the first-decile portfolio to 1.61 for the tenth-decile portfolio. Moreover, they are estimated very precisely; the standard errors are all below 0.04 . 
Table I: Pension Plan Funding Over Time. The table reports mean, median, standard deviation, minimum and maximum for the fair value of plan assets (FVPA), the projected benefit obligation (PBO), and the funding ratio $(F R)$, for all the companies that satisfy the selection criteria exposed in Section II. There are 36,651 company-years in the sample between 1990 and 2002. For each company the funding ratio $(F R)$ is the difference between FVPA and PBO divided by market value of equity at the end of the year. The FVPA and PBO are expressed in millions of dollars.

\begin{tabular}{|c|c|c|c|c|c|c|c|c|c|}
\hline \multirow[b]{3}{*}{ Mean } & \multicolumn{3}{|c|}{$1980-2002$} & \multicolumn{3}{|c|}{ 1980-1990 } & \multicolumn{3}{|c|}{ 1991-2002 } \\
\hline & FVPA & PBO & FR & FVPA & $\mathrm{PBO}$ & FR & FVPA & PBO & FR \\
\hline & 484.60 & 440.76 & 0.01 & 275.69 & 233.75 & 0.02 & 743.08 & 691.32 & -0.01 \\
\hline Median & 38.23 & 34.40 & 0.01 & 21.97 & 17.84 & 0.02 & 73.40 & 71.47 & 0.00 \\
\hline S.dev. & 2637.39 & 2452.95 & 0.22 & 1518.90 & 1295.33 & 0.18 & 3547.86 & 3339.84 & 0.25 \\
\hline Min. & 0.00 & 0.00 & -9.87 & 0.00 & 0.00 & -4.62 & 0.00 & 0.00 & -9.87 \\
\hline Max. & 87524.00 & 92243.00 & 5.72 & 46380.31 & 50991.40 & 5.72 & 87524.00 & 92243.00 & 2.07 \\
\hline
\end{tabular}


Table II: Descriptive Statistics. In July of year $t$, stocks with negative $F R$ in December of year $t-1$ are assigned to ten groups according to the deciles of the distribution of $F R$ for NYSE firms. The stocks in the first decile are the most underfunded and the stocks in the tenth decile are the least underfunded. The firms with nonnegative $F R$ are assigned to the eleventh group (OF for overfunded). Value-weighted $(\mathrm{VW})$ and equally weighted (EW) portfolios are formed. $F R$ is the difference between the fair value of plan assets and Projected Benefit Obligation in fiscal year ending in year $t-1$, divided by market capitalization in December of year $t-1$. Panel A reports the average of the annual averages of the $F R$ of the companies in each portfolio; the average of the annual averages of the market capitalization (in millions of dollars) of the companies in each portfolio in June of year $t$; the average of the annual averages of the book-to-market ratio $(\mathrm{B} / \mathrm{M})$ of the companies in each portfolio in December of year $t-1$; and the average of the annual number of firms in each portfolio. The sample covers formation periods from July 1981 to July 2003. Panel B reports means and standard deviations of the excess returns (return minus one-month T-bill rate) on the 25 sizeand FR-sorted portfolios. Panel $\mathrm{C}$ reports means and standard deviations for the returns on the four-factor portfolios EXM, HML, SMB, and UMD. EXM is the excess return on the CRSP value-weighted index. HML (high $\mathrm{B} / \mathrm{M}$ minus low $\mathrm{B} / \mathrm{M}$ ) and SMB (small minus big) are the returns on the Fama-French factors. UMD (up minus down) is the return on the momentum portfolio (long in past 12-month winners, and short in past 12-month losers). Percent returns range from July 1981 to December 2003.

\begin{tabular}{|c|c|c|c|c|c|c|c|c|c|c|c|}
\hline & 1 & 2 & 3 & 4 & 5 & 6 & 7 & 8 & 9 & 10 & $\mathrm{OF}$ \\
\hline \multicolumn{12}{|c|}{ Panel A: Portfolio Characteristics } \\
\hline FR & -0.468 & -0.115 & -0.060 & -0.037 & -0.024 & -0.016 & -0.010 & -0.006 & -0.003 & -0.001 & 0.065 \\
\hline Size & 613.7 & 865.0 & 1417.9 & 1743.4 & 2355.9 & 2213.1 & 2658.8 & 3120.9 & 3555.9 & 5587.8 & 3228.2 \\
\hline $\mathrm{B} / \mathrm{M}$ & 2.07 & 1.44 & 1.12 & 1.03 & 0.91 & 0.88 & 0.79 & 0.74 & 0.69 & 0.60 & 0.92 \\
\hline Firms & 68.3 & 64.5 & 65.2 & 64.8 & 59.7 & 60.4 & 59.7 & 61.4 & 62.7 & 66.0 & 960.4 \\
\hline \multicolumn{12}{|c|}{ Panel B: Returns } \\
\hline \multicolumn{12}{|c|}{ VW portfolios } \\
\hline Mean & 0.42 & 0.56 & 0.69 & 0.88 & 0.83 & 0.85 & 0.60 & 0.81 & 0.79 & 0.57 & 0.62 \\
\hline S.dev. & 7.49 & 6.09 & 5.58 & 4.45 & 4.68 & 4.68 & 5.06 & 5.08 & 5.08 & 5.22 & 4.28 \\
\hline \multicolumn{12}{|c|}{ EW portfolios } \\
\hline Mean & 0.48 & 0.55 & 0.72 & 0.78 & 0.73 & 0.73 & 0.67 & 0.77 & 0.53 & 0.66 & 0.80 \\
\hline S.dev. & 6.64 & 5.61 & 5.29 & 5.14 & 4.71 & 4.82 & 4.92 & 4.94 & 5.04 & 5.03 & 4.26 \\
\hline \multicolumn{12}{|c|}{ Panel C: Factors } \\
\hline & & & & & EXM & HML & SMB & UMD & & & \\
\hline & & & & Mean & 0.61 & 0.43 & 0.06 & 0.86 & & & \\
\hline & & & & S.dev. & 4.58 & 3.27 & 3.36 & 4.39 & & & \\
\hline
\end{tabular}


Table III: Raw Returns. In July of year $t$, stocks with negative $F R$ in December of year $t-1$ are assigned to ten groups according to the deciles of the distribution of $F R$ for NYSE firms. The stocks in the first decile are the most underfunded and the stocks in the tenth decile are the least underfunded. The firms with nonnegative $F R$ are assigned to the eleventh group (OF for overfunded). Value-weighted (VW) and equally weighted (EW) portfolios are formed. $F R$ is the difference between the fair value of plan assets and Projected Benefit Obligation in fiscal year ending in year $t-1$, divided by market capitalization in December of year $t-1$. Panel A and Panel B report compounded returns for VW and EW portfolios, respectively. Monthly returns are compounded in the first semester (S1), and in year $i$ after portfolio formation (Yi). The row labelled AR gives the average annual return over the first five years after portfolio formation. The sample period is from July 1981 to December 2003.

\begin{tabular}{|c|c|c|c|c|c|c|c|c|c|c|c|}
\hline & 1 & 2 & 3 & 4 & 5 & 6 & 7 & 8 & 9 & 10 & $\mathrm{OF}$ \\
\hline \multicolumn{12}{|c|}{ Panel A: Value-Weighted Portfolios } \\
\hline S1 & -0.55 & 1.88 & 3.44 & 6.67 & 6.38 & 6.71 & 5.14 & 4.04 & 5.61 & 4.88 & 5.22 \\
\hline Y1 & 9.36 & 11.68 & 13.67 & 16.89 & 16.60 & 16.15 & 13.29 & 16.08 & 15.72 & 13.03 & 13.94 \\
\hline Y2 & 7.17 & 18.64 & 14.69 & 16.99 & 15.29 & 12.61 & 19.40 & 17.42 & 16.13 & 17.91 & 15.27 \\
\hline Y3 & 8.23 & 11.76 & 8.55 & 12.86 & 12.68 & 12.40 & 12.83 & 15.05 & 11.87 & 13.53 & 13.44 \\
\hline Y4 & 6.81 & 10.62 & 12.83 & 13.31 & 15.75 & 13.89 & 14.98 & 12.43 & 14.04 & 14.15 & 14.36 \\
\hline Y5 & 5.52 & 13.45 & 9.96 & 13.15 & 12.78 & 19.07 & 13.73 & 8.86 & 13.17 & 18.38 & 13.49 \\
\hline AR & 7.42 & 13.23 & 11.94 & 14.64 & 14.62 & 14.82 & 14.84 & 13.97 & 14.19 & 15.40 & 14.10 \\
\hline \multicolumn{12}{|c|}{ Panel B: Equally Weighted Portfolios } \\
\hline S1 & -4.02 & -1.50 & 1.04 & 1.45 & 2.41 & 2.47 & 2.69 & 3.45 & 1.64 & 3.98 & 4.02 \\
\hline Y1 & 10.35 & 11.15 & 14.56 & 15.51 & 15.44 & 14.45 & 14.10 & 14.98 & 11.61 & 13.52 & 16.20 \\
\hline Y2 & 12.66 & 14.08 & 15.78 & 17.59 & 18.48 & 15.79 & 15.37 & 15.87 & 15.12 & 15.58 & 17.05 \\
\hline Y3 & 7.01 & 12.09 & 12.58 & 13.34 & 9.98 & 13.54 & 14.69 & 11.09 & 11.00 & 12.04 & 13.91 \\
\hline Y4 & 7.78 & 14.28 & 11.92 & 15.04 & 14.24 & 11.07 & 12.59 & 12.78 & 13.59 & 14.89 & 15.19 \\
\hline Y5 & 6.63 & 13.67 & 10.87 & 13.79 & 16.41 & 11.72 & 13.92 & 9.57 & 14.62 & 13.68 & 14.44 \\
\hline AR & 8.89 & 13.05 & 13.14 & 15.05 & 14.91 & 13.32 & 14.13 & 12.86 & 13.19 & 13.94 & 15.36 \\
\hline
\end{tabular}


Table IV: Three-Factor Model. In July of year $t$, stocks with negative $F R$ in December of year $t-1$ are assigned to ten groups according to the deciles of the distribution of $F R$ for NYSE firms. The stocks in the first decile are the most underfunded and the stocks in the tenth decile are the least underfunded. The firms with nonnegative $F R$ are assigned to the eleventh group (OF for overfunded). Value-weighted (VW) and equally weighted (EW) portfolios are formed. $F R$ is the difference between the fair value of plan assets and Projected Benefit Obligation in fiscal year ending in year $t-1$, divided by market capitalization in December of year $t-1$. Panel A reports the constant (alpha) from a time-series regression of portfolio excess returns on the three Fama-French factors, which the market excess return (EXM), the return on the HML portfolio, and the return on the SMB portfolio. Both VW and EW portfolios are considered. Panel B reports the slopes and adjusted $\mathrm{R}^{2}$ from these regressions. The sample period is from July 1981 to December 2003. $t$-statistics are reported in parentheses.

\begin{tabular}{|c|c|c|c|c|c|c|c|c|c|c|c|}
\hline & 1 & 2 & 3 & 4 & 5 & 6 & 7 & 8 & 9 & 10 & $\mathrm{OF}$ \\
\hline \multicolumn{12}{|c|}{ Panel A: Alphas } \\
\hline VW & $\begin{array}{c}-0.89 \\
(-2.69)\end{array}$ & $\begin{array}{c}-0.48 \\
(-2.21)\end{array}$ & $\begin{array}{c}-0.26 \\
(-1.33)\end{array}$ & $\begin{array}{c}0.16 \\
(0.86)\end{array}$ & $\begin{array}{c}0.16 \\
(0.86)\end{array}$ & $\begin{array}{c}0.15 \\
(0.93)\end{array}$ & $\begin{array}{c}-0.05 \\
(-0.27)\end{array}$ & $\begin{array}{c}0.08 \\
(0.51)\end{array}$ & $\begin{array}{c}0.15 \\
(0.87)\end{array}$ & $\begin{array}{c}-0.01 \\
(-0.06)\end{array}$ & $\begin{array}{c}-0.07 \\
(-1.24)\end{array}$ \\
\hline EW & $\begin{array}{c}-0.68 \\
(-2.61)\end{array}$ & $\begin{array}{c}-0.48 \\
(-2.51)\end{array}$ & $\begin{array}{c}-0.22 \\
(-1.30)\end{array}$ & $\begin{array}{c}-0.19 \\
(-1.10)\end{array}$ & $\begin{array}{c}-0.11 \\
(-0.77)\end{array}$ & $\begin{array}{c}-0.15 \\
(-1.05)\end{array}$ & $\begin{array}{c}-0.15 \\
(-0.96)\end{array}$ & $\begin{array}{c}-0.06 \\
(-0.45)\end{array}$ & $\begin{array}{c}-0.30 \\
(-2.19)\end{array}$ & $\begin{array}{c}-0.14 \\
(-1.14)\end{array}$ & $\begin{array}{c}-0.05 \\
(-0.55)\end{array}$ \\
\hline \multicolumn{12}{|c|}{ Panel B: Factor Loadings and $\mathrm{R}^{2}$} \\
\hline \multicolumn{12}{|c|}{ VW Portfolios } \\
\hline EXM & $\begin{array}{c}1.38 \\
(16.94)\end{array}$ & $\begin{array}{c}1.24 \\
(23.34)\end{array}$ & $\begin{array}{c}1.17 \\
(24.48)\end{array}$ & $\begin{array}{c}0.86 \\
(19.28)\end{array}$ & $\begin{array}{c}0.89 \\
(19.43)\end{array}$ & $\begin{array}{c}0.95 \\
(23.95)\end{array}$ & $\begin{array}{c}0.97 \\
(21.60)\end{array}$ & $\begin{array}{c}1.03 \\
(25.30)\end{array}$ & $\begin{array}{c}0.99 \\
(23.65)\end{array}$ & $\begin{array}{c}1.02 \\
(28.24)\end{array}$ & $\begin{array}{c}0.99 \\
(76.31)\end{array}$ \\
\hline HML & $\begin{array}{c}1.03 \\
(8.21)\end{array}$ & $\begin{array}{c}0.60 \\
(7.38)\end{array}$ & $\begin{array}{c}0.54 \\
(7.34)\end{array}$ & $\begin{array}{c}0.44 \\
(6.47)\end{array}$ & $\begin{array}{c}0.29 \\
(4.19)\end{array}$ & $\begin{array}{c}0.28 \\
(4.66)\end{array}$ & $\begin{array}{c}0.14 \\
(1.97)\end{array}$ & $\begin{array}{c}0.23 \\
(3.65)\end{array}$ & $\begin{array}{c}0.11 \\
(1.73)\end{array}$ & $\begin{array}{c}-0.06 \\
(-1.16)\end{array}$ & $\begin{array}{c}0.22 \\
(10.76)\end{array}$ \\
\hline SMB & $\begin{array}{c}0.35 \\
(3.34)\end{array}$ & $\begin{array}{c}0.29 \\
(4.17)\end{array}$ & $\begin{array}{c}0.03 \\
(0.55)\end{array}$ & $\begin{array}{c}0.03 \\
(0.53)\end{array}$ & $\begin{array}{c}0.02 \\
(0.33)\end{array}$ & $\begin{array}{c}0.04 \\
(0.72)\end{array}$ & $\begin{array}{c}-0.11 \\
(-1.89)\end{array}$ & $\begin{array}{c}-0.01 \\
(-0.12)\end{array}$ & $\begin{array}{c}-0.14 \\
(-2.57)\end{array}$ & $\begin{array}{c}-0.29 \\
(-6.18)\end{array}$ & $\begin{array}{c}-0.22 \\
(-12.82)\end{array}$ \\
\hline $\mathrm{R}^{2}$ & 0.52 & 0.69 & 0.70 & 0.59 & 0.61 & 0.71 & 0.68 & 0.74 & 0.72 & 0.81 & 0.96 \\
\hline \multicolumn{12}{|c|}{ EW Portfolios } \\
\hline$\overline{\mathrm{EXM}}$ & $\begin{array}{c}1.17 \\
(18.15)\end{array}$ & $\begin{array}{c}1.06 \\
(22.48)\end{array}$ & $\begin{array}{c}1.05 \\
(25.53)\end{array}$ & $\begin{array}{c}1.00 \\
(23.94)\end{array}$ & $\begin{array}{c}0.97 \\
(26.59)\end{array}$ & $\begin{array}{c}1.00 \\
(28.62)\end{array}$ & $\begin{array}{c}0.99 \\
(25.98)\end{array}$ & $\begin{array}{c}1.02 \\
(30.56)\end{array}$ & $\begin{array}{c}1.04 \\
(30.63)\end{array}$ & $\begin{array}{c}1.06 \\
(34.00)\end{array}$ & $\begin{array}{c}0.98 \\
(44.81)\end{array}$ \\
\hline HML & $\begin{array}{c}0.89 \\
(9.04)\end{array}$ & $\begin{array}{c}0.77 \\
(10.62)\end{array}$ & $\begin{array}{c}0.60 \\
(9.52)\end{array}$ & $\begin{array}{c}0.72 \\
(11.26)\end{array}$ & $\begin{array}{c}0.52 \\
(9.36)\end{array}$ & $\begin{array}{c}0.54 \\
(10.13)\end{array}$ & $\begin{array}{c}0.42 \\
(7.18)\end{array}$ & $\begin{array}{c}0.41 \\
(8.00)\end{array}$ & $\begin{array}{c}0.39 \\
(7.43)\end{array}$ & $\begin{array}{c}0.31 \\
(6.55)\end{array}$ & $\begin{array}{c}0.53 \\
(15.96)\end{array}$ \\
\hline SMB & $\begin{array}{c}0.88 \\
(10.54)\end{array}$ & $\begin{array}{c}0.78 \\
(12.80)\end{array}$ & $\begin{array}{c}0.62 \\
(11.72)\end{array}$ & $\begin{array}{c}0.67 \\
(12.43)\end{array}$ & $\begin{array}{c}0.45 \\
(9.55)\end{array}$ & $\begin{array}{c}0.48 \\
(10.69)\end{array}$ & $\begin{array}{c}0.40 \\
(8.18)\end{array}$ & $\begin{array}{c}0.44 \\
(10.11)\end{array}$ & $\begin{array}{c}0.40 \\
(9.17)\end{array}$ & $\begin{array}{c}0.34 \\
(8.36)\end{array}$ & $\begin{array}{c}0.34 \\
(12.18)\end{array}$ \\
\hline $\mathrm{R}^{2}$ & 0.62 & 0.71 & 0.76 & 0.73 & 0.76 & 0.79 & 0.75 & 0.81 & 0.81 & 0.84 & 0.89 \\
\hline
\end{tabular}


Table V: Four-Factor Model. In July of year $t$, stocks with negative $F R$ in December of year $t-1$ are assigned to ten groups according to the deciles of the distribution of $F R$ for NYSE firms. The stocks in the first decile are the most underfunded and the stocks in the tenth decile are the least underfunded. The firms with nonnegative $F R$ are assigned to the eleventh group (OF for overfunded). Value-weighted $(\mathrm{VW})$ and equally weighted (EW) portfolios are formed. $F R$ is the difference between the fair value of plan assets and Projected Benefit Obligation in fiscal year ending in year $t-1$, divided by market capitalization in December of year $t-1$. Panel A reports the constant (alpha) from a time-series regression of portfolio excess returns on four factors, the market excess return (EXM), the return on the HML portfolio, the return on the SMB portfolio, and the return on a momentum portfolio (UMD). Both VW and EW portfolios are considered. Panel B reports the slopes and adjusted $\mathrm{R}^{2}$ from these regressions. The sample is July 1981 to December 2003. $t$-statistics are reported in parentheses.

\begin{tabular}{|c|c|c|c|c|c|c|c|c|c|c|c|}
\hline & 1 & 2 & 3 & 4 & 5 & 6 & 7 & 8 & 9 & 10 & OF \\
\hline \multicolumn{12}{|c|}{ Panel A: Alphas } \\
\hline VW & $\begin{array}{c}-0.76 \\
(-2.25)\end{array}$ & $\begin{array}{c}-0.36 \\
(-1.63)\end{array}$ & $\begin{array}{c}-0.18 \\
(-0.93)\end{array}$ & $\begin{array}{c}0.25 \\
(1.38)\end{array}$ & $\begin{array}{c}0.11 \\
(0.56)\end{array}$ & $\begin{array}{c}0.12 \\
(0.71)\end{array}$ & $\begin{array}{c}-0.04 \\
(-0.24)\end{array}$ & $\begin{array}{c}0.04 \\
(0.25)\end{array}$ & $\begin{array}{c}0.05 \\
(0.30)\end{array}$ & $\begin{array}{c}-0.01 \\
(-0.07)\end{array}$ & $\begin{array}{c}-0.01 \\
(-0.26)\end{array}$ \\
\hline EW & $\begin{array}{c}-0.35 \\
(-1.39)\end{array}$ & $\begin{array}{c}-0.24 \\
(-1.30)\end{array}$ & $\begin{array}{c}0.01 \\
(0.09)\end{array}$ & $\begin{array}{c}0.10 \\
(0.64)\end{array}$ & $\begin{array}{c}-0.01 \\
(-0.06)\end{array}$ & $\begin{array}{c}0.01 \\
(0.04)\end{array}$ & $\begin{array}{c}0.05 \\
(0.34)\end{array}$ & $\begin{array}{c}0.07 \\
(0.49)\end{array}$ & $\begin{array}{c}-0.08 \\
(-0.61)\end{array}$ & $\begin{array}{c}-0.03 \\
(-0.23)\end{array}$ & $\begin{array}{c}0.08 \\
(0.90)\end{array}$ \\
\hline \multicolumn{12}{|c|}{ Panel B: Factor Loadings and $\mathrm{R}^{2}$} \\
\hline \multicolumn{12}{|c|}{ VW Portfolios } \\
\hline EXM & $\begin{array}{c}1.35 \\
(16.42)\end{array}$ & $\begin{array}{c}1.22 \\
(22.73)\end{array}$ & $\begin{array}{c}1.16 \\
(23.87)\end{array}$ & $\begin{array}{c}0.85 \\
(18.71)\end{array}$ & $\begin{array}{c}0.90 \\
(19.35)\end{array}$ & $\begin{array}{c}0.95 \\
(23.70)\end{array}$ & $\begin{array}{c}0.97 \\
(21.20)\end{array}$ & $\begin{array}{c}1.04 \\
(25.08)\end{array}$ & $\begin{array}{c}1.01 \\
(23.90)\end{array}$ & $\begin{array}{c}1.02 \\
(27.74)\end{array}$ & $\begin{array}{c}0.98 \\
(76.67)\end{array}$ \\
\hline HML & $\begin{array}{c}1.00 \\
(7.97)\end{array}$ & $\begin{array}{c}0.58 \\
(7.10)\end{array}$ & $\begin{array}{c}0.52 \\
(7.10)\end{array}$ & $\begin{array}{c}0.43 \\
(6.18)\end{array}$ & $\begin{array}{c}0.31 \\
(4.32)\end{array}$ & $\begin{array}{c}0.29 \\
(4.72)\end{array}$ & $\begin{array}{c}0.14 \\
(1.94)\end{array}$ & $\begin{array}{c}0.24 \\
(3.75)\end{array}$ & $\begin{array}{c}0.13 \\
(2.03)\end{array}$ & $\begin{array}{c}-0.06 \\
(-1.14)\end{array}$ & $\begin{array}{c}0.20 \\
(10.49)\end{array}$ \\
\hline SMB & $\begin{array}{c}0.36 \\
(3.45)\end{array}$ & $\begin{array}{c}0.30 \\
(4.35)\end{array}$ & $\begin{array}{c}0.04 \\
(0.66)\end{array}$ & $\begin{array}{c}0.04 \\
(0.69)\end{array}$ & $\begin{array}{c}0.01 \\
(0.25)\end{array}$ & $\begin{array}{c}0.03 \\
(0.66)\end{array}$ & $\begin{array}{c}-0.11 \\
(-1.87)\end{array}$ & $\begin{array}{c}-0.01 \\
(-0.19)\end{array}$ & $\begin{array}{l}-0.15 \\
(-2.75)\end{array}$ & $\begin{array}{c}-0.29 \\
(-6.16)\end{array}$ & $\begin{array}{c}-0.21 \\
(-12.91)\end{array}$ \\
\hline UMD & $\begin{array}{c}-0.12 \\
(-1.64)\end{array}$ & $\begin{array}{c}-0.11 \\
(-2.30)\end{array}$ & $\begin{array}{c}-0.07 \\
(-1.59)\end{array}$ & $\begin{array}{c}-0.09 \\
(-2.31)\end{array}$ & $\begin{array}{c}0.05 \\
(1.21)\end{array}$ & $\begin{array}{c}0.03 \\
(0.84)\end{array}$ & $\begin{array}{c}0.00 \\
(-0.09)\end{array}$ & $\begin{array}{c}0.04 \\
(1.03)\end{array}$ & $\begin{array}{c}0.09 \\
(2.38)\end{array}$ & $\begin{array}{c}0.00 \\
(0.07)\end{array}$ & $\begin{array}{c}-0.05 \\
(-4.23)\end{array}$ \\
\hline $\mathrm{R}^{2}$ & 0.52 & 0.69 & 0.70 & 0.59 & 0.61 & 0.71 & 0.68 & 0.74 & 0.73 & 0.80 & 0.96 \\
\hline \multicolumn{12}{|c|}{ EW Portfolios } \\
\hline EXM & $\begin{array}{c}1.11 \\
(17.84)\end{array}$ & $\begin{array}{c}1.01 \\
(22.32)\end{array}$ & $\begin{array}{c}1.00 \\
(25.71)\end{array}$ & $\begin{array}{c}0.95 \\
(24.71)\end{array}$ & $\begin{array}{c}0.95 \\
(26.01)\end{array}$ & $\begin{array}{c}0.97 \\
(28.43)\end{array}$ & $\begin{array}{c}0.95 \\
(26.01)\end{array}$ & $\begin{array}{c}1.00 \\
(30.19)\end{array}$ & $\begin{array}{c}1.00 \\
(31.74)\end{array}$ & $\begin{array}{c}1.04 \\
(33.64)\end{array}$ & $\begin{array}{c}0.95 \\
(46.09)\end{array}$ \\
\hline HML & $\begin{array}{c}0.83 \\
(8.77)\end{array}$ & $\begin{array}{c}0.72 \\
(10.42)\end{array}$ & $\begin{array}{c}0.55 \\
(9.32)\end{array}$ & $\begin{array}{c}0.67 \\
(11.41)\end{array}$ & $\begin{array}{c}0.50 \\
(9.05)\end{array}$ & $\begin{array}{c}0.51 \\
(9.87)\end{array}$ & $\begin{array}{c}0.38 \\
(6.83)\end{array}$ & $\begin{array}{c}0.39 \\
(7.67)\end{array}$ & $\begin{array}{c}0.34 \\
(7.16)\end{array}$ & $\begin{array}{c}0.29 \\
(6.18)\end{array}$ & $\begin{array}{c}0.51 \\
(16.17)\end{array}$ \\
\hline SMB & $\begin{array}{c}0.91 \\
(11.47)\end{array}$ & $\begin{array}{c}0.80 \\
(13.83)\end{array}$ & $\begin{array}{c}0.64 \\
(12.90)\end{array}$ & $\begin{array}{c}0.70 \\
(14.28)\end{array}$ & $\begin{array}{c}0.46 \\
(9.87)\end{array}$ & $\begin{array}{c}0.50 \\
(11.41)\end{array}$ & $\begin{array}{c}0.42 \\
(9.02)\end{array}$ & $\begin{array}{c}0.45 \\
(10.64)\end{array}$ & $\begin{array}{c}0.42 \\
(10.54)\end{array}$ & $\begin{array}{c}0.35 \\
(8.83)\end{array}$ & $\begin{array}{c}0.35 \\
(13.44)\end{array}$ \\
\hline UMD & $\begin{array}{c}-0.31 \\
(-5.57)\end{array}$ & $\begin{array}{l}-0.22 \\
(-5.49)\end{array}$ & $\begin{array}{l}-0.22 \\
(-6.18)\end{array}$ & $\begin{array}{c}-0.27 \\
(-7.86)\end{array}$ & $\begin{array}{l}-0.10 \\
(-3.00)\end{array}$ & $\begin{array}{l}-0.15 \\
(-4.77)\end{array}$ & $\begin{array}{l}-0.19 \\
(-5.70)\end{array}$ & $\begin{array}{l}-0.12 \\
(-4.04)\end{array}$ & $\begin{array}{l}-0.21 \\
(-7.42)\end{array}$ & $\begin{array}{l}-0.11 \\
(-3.94)\end{array}$ & $\begin{array}{l}-0.12 \\
(-6.34)\end{array}$ \\
\hline $\mathrm{R}^{2}$ & 0.66 & 0.74 & 0.79 & 0.78 & 0.77 & 0.80 & 0.78 & 0.82 & 0.85 & 0.85 & 0.91 \\
\hline
\end{tabular}


Table VI: Measures of Surprise. In July of year $t$, stocks with negative $F R$ in December of year $t-1$ are assigned to ten groups according to the deciles of the distribution of $F R$ for NYSE firms. The stocks in the first decile are the most underfunded and the stocks in the tenth decile are the least underfunded. The firms with nonnegative $F R$ are assigned to the eleventh group (OF for overfunded). $F R$ is the difference between the fair value of plan assets and Projected Benefit Obligation in fiscal year ending in year $t-1$, divided by market capitalization in December of year $t-1$. Panel A reports cumulative returns around earnings announcements. Returns are summed from one day before the announcement to one day after, and averaged across the stocks in each portfolio during each quarter. Then, the quarterly portfolio surprises are added to form the cumulative portfolio surprise in the period of interest. The periods that are considered range from one quarter (Q1) to the fifth year (Y5) after portfolio formation. Panel B reports risk-adjusted cumulative returns around earnings announcements. Returns are relative to a Fama-French three-factor model, where the factor loadings are the full sample loadings of the $F R$ portfolio to which the stock belongs in that formation period. The same aggregation procedure applies as in Panel A. Panel C reports standardized unexpected earnings (the change in quarterly earnings per share from its value four quarters before, divided by the standard deviation of this quantity over the previous eight quarters). The quarterly standardized unexpected earnings are averaged across the stocks in the portfolios and then added over different periods. Panel D reports the percentage revision in analysts' forecasts. For each company in each month, the monthly change in the median forecast of the current fiscal year earnings is divided by the stock price in the previous month. This percentage revision is averaged across stocks in the portfolio in each month and then summed over the period of interest. The periods considered range from the first semester (S1) to the fifth year (Y5) after portfolio formation. For each panel, the last column reports the $t$-statistic for the test of the hypothesis that the difference in the quantity of interest between the overfunded portfolio and $F R$ portfolio one is equal to zero over the sample period. The sample period is between July 1981 and December 2003.

\begin{tabular}{cccccccccccccc}
\hline \hline & 1 & 2 & 3 & 4 & 5 & 6 & 7 & 8 & 9 & 10 & OF & $t$-stat(OF-1) \\
\hline \multicolumn{10}{c}{ Panel A: Cumulative Returns } & Around Earnings Announcements \\
\hline Q1 & -0.010 & -0.007 & 0.002 & 0.002 & -0.003 & 0.004 & 0.002 & 0.004 & 0.003 & 0.000 & 0.003 & 1.519 \\
Y1 & -0.002 & 0.001 & 0.009 & 0.013 & 0.010 & 0.011 & 0.010 & 0.009 & 0.012 & 0.009 & 0.011 & 2.211 \\
Y2 & 0.008 & 0.004 & 0.010 & 0.017 & 0.017 & 0.016 & 0.008 & 0.007 & 0.006 & 0.007 & 0.011 & 0.744 \\
Y3 & 0.001 & 0.015 & 0.011 & 0.018 & 0.002 & 0.016 & 0.009 & 0.006 & 0.012 & 0.014 & 0.008 & 0.799 \\
Y4 & 0.004 & 0.003 & 0.010 & 0.011 & 0.008 & 0.015 & 0.007 & 0.010 & 0.015 & 0.015 & 0.010 & 0.793 \\
Y5 & 0.000 & 0.010 & 0.012 & 0.014 & 0.002 & 0.010 & 0.010 & 0.006 & 0.012 & 0.013 & 0.011 & 1.322 \\
\hline \multicolumn{1}{c}{ Panel B: Adjusted Cumulative Returns Around Earnings Announcements } \\
\hline Q1 & -0.004 & -0.006 & 0.000 & 0.003 & -0.002 & -0.001 & -0.001 & 0.000 & 0.000 & -0.001 & 0.000 & 2.617 \\
Y1 & -0.010 & -0.003 & 0.003 & 0.007 & 0.002 & 0.005 & 0.006 & 0.003 & 0.007 & 0.000 & 0.004 & 2.802 \\
Y2 & -0.004 & 0.002 & 0.005 & 0.006 & 0.005 & 0.003 & 0.006 & 0.003 & 0.001 & 0.005 & 0.003 & 0.984 \\
Y3 & -0.006 & 0.005 & 0.004 & 0.008 & 0.000 & 0.007 & 0.004 & 0.000 & 0.008 & 0.005 & 0.002 & 1.143 \\
Y4 & -0.009 & 0.000 & 0.006 & 0.007 & 0.001 & 0.012 & 0.003 & 0.008 & 0.001 & 0.010 & 0.003 & 1.919 \\
Y5 & -0.014 & 0.006 & -0.002 & 0.006 & -0.003 & 0.005 & 0.010 & 0.005 & 0.001 & 0.001 & 0.004 & 2.519 \\
\hline
\end{tabular}


Table VI: Continued

\begin{tabular}{cccccccccccccc}
\hline \hline & 1 & 2 & 3 & 4 & 5 & 6 & 7 & 8 & 9 & 10 & OF & $t$-stat(OF-1) \\
\hline \multicolumn{10}{c}{} & & \multicolumn{1}{c}{ Panel C: Standardized Unexpected Earnings } \\
\hline Q1 & -0.076 & -0.099 & 0.055 & 0.113 & 0.106 & 0.168 & 0.236 & 0.367 & 0.421 & 0.541 & 0.326 & 5.760 \\
Y1 & -0.256 & -0.204 & 0.335 & 0.299 & 0.538 & 0.777 & 0.936 & 1.174 & 1.417 & 1.912 & 1.208 & 5.740 \\
Y2 & 0.207 & 0.012 & 0.353 & 0.617 & 0.668 & 0.693 & 0.950 & 0.911 & 1.398 & 1.648 & 1.185 & 4.850 \\
Y3 & 0.062 & 0.020 & 0.426 & 0.758 & 0.838 & 1.111 & 0.710 & 0.974 & 1.738 & 1.489 & 1.266 & 7.200 \\
Y4 & -0.157 & 0.260 & 0.140 & 0.898 & 0.699 & 0.653 & 1.010 & 1.040 & 1.236 & 1.700 & 1.139 & 7.509 \\
Y5 & -0.084 & 0.328 & 0.119 & 0.764 & 0.692 & 0.631 & 1.124 & 1.217 & 1.393 & 1.671 & 1.104 & 4.682 \\
\hline & & & \multicolumn{1}{c}{ Panel D: Revisions in Analyst Forecast $(\%)$} & & & \\
\hline S1 & -0.058 & -0.033 & -0.015 & -0.013 & -0.008 & -0.010 & -0.007 & -0.008 & -0.004 & -0.004 & -0.009 & 3.995 \\
Y1 & -0.057 & -0.026 & -0.010 & -0.013 & -0.007 & -0.007 & -0.005 & -0.006 & -0.004 & -0.002 & -0.005 & 3.034 \\
Y2 & -0.047 & -0.015 & -0.003 & -0.008 & -0.009 & -0.006 & 0.003 & -0.009 & -0.003 & 0.003 & -0.005 & 2.473 \\
Y3 & -0.055 & -0.007 & -0.010 & -0.007 & -0.011 & -0.002 & -0.001 & -0.003 & -0.003 & -0.004 & -0.004 & 3.442 \\
Y4 & -0.024 & -0.026 & -0.012 & -0.008 & -0.005 & -0.005 & -0.008 & -0.010 & -0.003 & -0.001 & -0.004 & 1.424 \\
Y5 & -0.068 & -0.013 & -0.015 & -0.003 & -0.002 & -0.006 & 0.005 & -0.005 & -0.003 & 0.006 & -0.004 & 1.993 \\
\hline \hline
\end{tabular}


Table VII: Portfolio Characteristics. In July of year $t$, stocks with negative $F R$ in December of year $t-1$ are assigned to ten groups according to the deciles of the distribution of $F R$ for NYSE firms. The stocks in the first decile are the most underfunded and the stocks in the tenth decile are the least underfunded. The firms with nonnegative $F R$ are assigned to the eleventh group (OF for overfunded). $F R$ is the difference between the fair value of plan assets and Projected Benefit Obligation in fiscal year ending in year $t-1$, divided by market capitalization in December of year $t-1$. Panel A reports compound equally weighted portfolio returns. The compounding periods range from the first semester (-S1) and to the third year (-Y3) before portfolio formation. Panel B reports standardized unexpected earnings (the change in quarterly earnings per share from its value four quarters before, divided by the standard deviation of this quantity over the previous eight quarters). The quarterly standardized unexpected earnings are averaged across the stocks in the portfolios and then summed over different periods. The periods that are considered range from the first semester (-S1) and to the third year (-Y3) before portfolio formation. Panel C reports the average accrual to asset ratio for the companies in the portfolio. Panel D reports the ratio of total earnings for the companies in the portfolio divided by total assets in the fiscal year under consideration. Panel E reports the ratio of total cash flows for the companies in the portfolio divided by total assets in the fiscal year under consideration. Panel F reports the growth rate of total sales for the companies in the portfolio. Panel G reports Ohlson's (1980) measure of bankruptcy risk computed using accounting data for the year under consideration. A higher value of this measure signifies a higher probability of bankruptcy. Panel H reports Altman's (1968) measure of bankruptcy risk computed using accounting data for the year under consideration. A lower value of this measure signifies a higher probability of bankruptcy. The fiscal years considered in all panels, except for the first two, range from the third year before portfolio formation (-Y3) to the third fiscal year ending after portfolio formation (Y3).

\begin{tabular}{ccccccccccccc}
\hline \hline & 1 & 2 & 3 & 4 & 5 & 6 & 7 & 8 & 9 & 10 & OF \\
\hline \multicolumn{10}{c}{ Panel A: Raw Returns } \\
\hline$-\mathrm{Y} 3$ & 5.66 & 11.56 & 13.64 & 17.34 & 20.69 & 18.82 & 24.96 & 24.76 & 24.25 & 29.84 & 19.12 \\
$-\mathrm{Y} 2$ & 1.08 & 8.24 & 10.45 & 15.22 & 14.67 & 18.58 & 21.37 & 25.81 & 24.97 & 29.83 & 18.17 \\
$-\mathrm{Y} 1$ & 6.64 & 11.50 & 13.22 & 12.48 & 16.00 & 16.87 & 14.83 & 20.32 & 18.56 & 19.24 & 17.25 \\
$-\mathrm{S} 1$ & 21.82 & 15.88 & 14.86 & 12.87 & 14.13 & 12.84 & 9.32 & 11.79 & 10.32 & 10.12 & 12.35 \\
\hline \multicolumn{10}{c}{ Panel B: Standardized Unexpected Earnings } \\
\hline$-\mathrm{Y} 3$ & -0.66 & -0.15 & 0.29 & 0.81 & 1.33 & 1.10 & 2.07 & 2.26 & 2.45 & 3.83 & 1.87 \\
$-\mathrm{Y} 2$ & -0.98 & -0.58 & -0.02 & 0.51 & 0.82 & 1.01 & 1.55 & 2.13 & 2.49 & 3.35 & 1.50 \\
$-\mathrm{Y} 1$ & -0.65 & -0.32 & -0.08 & 0.12 & 0.43 & 0.77 & 1.18 & 1.83 & 2.00 & 2.85 & 1.26 \\
$-\mathrm{S} 1$ & -0.03 & 0.09 & 0.08 & 0.02 & 0.13 & 0.17 & 0.26 & 0.40 & 0.52 & 0.60 & 0.33 \\
\hline \multicolumn{8}{c}{} & & \multicolumn{7}{c}{ Panel C: Accruals } & & & & \\
\hline$-\mathrm{Y} 3$ & -0.05 & -0.03 & -0.03 & -0.03 & -0.03 & -0.03 & -0.03 & -0.02 & -0.02 & -0.02 & -0.03 \\
$-\mathrm{Y} 2$ & -0.04 & -0.04 & -0.04 & -0.03 & -0.03 & -0.03 & -0.03 & -0.02 & -0.02 & -0.02 & -0.03 \\
$-\mathrm{Y} 1$ & -0.06 & -0.05 & -0.04 & -0.04 & -0.04 & -0.03 & -0.03 & -0.03 & -0.02 & -0.02 & -0.04 \\
Y1 & -0.06 & -0.05 & -0.05 & -0.04 & -0.04 & -0.04 & -0.04 & -0.03 & -0.04 & -0.03 & -0.04 \\
Y2 & -0.06 & -0.05 & -0.05 & -0.04 & -0.04 & -0.04 & -0.04 & -0.03 & -0.04 & -0.03 & -0.04 \\
Y3 & -0.05 & -0.05 & -0.04 & -0.04 & -0.04 & -0.04 & -0.04 & -0.04 & -0.04 & -0.04 & -0.04 \\
\hline
\end{tabular}


Table VII: Continued

\begin{tabular}{|c|c|c|c|c|c|c|c|c|c|c|c|}
\hline & 1 & 2 & 3 & 4 & 5 & 6 & 7 & 8 & 9 & 10 & $\mathrm{OF}$ \\
\hline \multicolumn{12}{|c|}{ Panel D: Earnings to Assets } \\
\hline$-Y 3$ & 0.002 & 0.024 & 0.024 & 0.036 & 0.033 & 0.035 & 0.031 & 0.027 & 0.039 & 0.041 & 0.034 \\
\hline$-Y 2$ & -0.004 & 0.014 & 0.030 & 0.033 & 0.035 & 0.035 & 0.033 & 0.034 & 0.040 & 0.039 & 0.033 \\
\hline$-Y 1$ & -0.016 & 0.010 & 0.027 & 0.028 & 0.037 & 0.033 & 0.033 & 0.036 & 0.038 & 0.038 & 0.031 \\
\hline Y1 & -0.025 & 0.004 & 0.032 & 0.030 & 0.034 & 0.033 & 0.028 & 0.028 & 0.038 & 0.036 & 0.029 \\
\hline Y2 & -0.001 & -0.001 & 0.028 & 0.034 & 0.029 & 0.029 & 0.031 & 0.030 & 0.034 & 0.036 & 0.028 \\
\hline Y3 & -0.004 & 0.005 & 0.029 & 0.033 & 0.029 & 0.029 & 0.032 & 0.030 & 0.034 & 0.033 & 0.028 \\
\hline \multicolumn{12}{|c|}{ Panel E: Cash Flows to Assets } \\
\hline$-Y 3$ & 0.050 & 0.056 & 0.065 & 0.072 & 0.067 & 0.061 & 0.058 & 0.053 & 0.064 & 0.063 & 0.061 \\
\hline$-Y 2$ & 0.045 & 0.046 & 0.071 & 0.070 & 0.070 & 0.062 & 0.060 & 0.059 & 0.065 & 0.060 & 0.060 \\
\hline$-Y 1$ & 0.035 & 0.043 & 0.068 & 0.065 & 0.069 & 0.060 & 0.060 & 0.060 & 0.064 & 0.059 & 0.058 \\
\hline Y1 & 0.026 & 0.037 & 0.072 & 0.067 & 0.067 & 0.060 & 0.056 & 0.053 & 0.064 & 0.056 & 0.056 \\
\hline Y2 & 0.049 & 0.032 & 0.067 & 0.071 & 0.062 & 0.057 & 0.058 & 0.055 & 0.060 & 0.057 & 0.055 \\
\hline Y3 & 0.045 & 0.038 & 0.069 & 0.070 & 0.062 & 0.056 & 0.058 & 0.055 & 0.060 & 0.056 & 0.055 \\
\hline \multicolumn{12}{|c|}{ Panel F: Sales Growth } \\
\hline -Y3 & 0.008 & 0.040 & 0.018 & 0.007 & 0.050 & 0.035 & 0.041 & 0.059 & 0.059 & 0.078 & 0.064 \\
\hline$-\mathrm{Y} 2$ & -0.002 & 0.034 & 0.049 & 0.030 & 0.055 & 0.052 & 0.076 & 0.139 & 0.119 & 0.069 & 0.058 \\
\hline$-\mathrm{Y} 1$ & 0.014 & 0.059 & 0.034 & 0.045 & 0.043 & 0.105 & 0.089 & 0.098 & 0.092 & 0.124 & 0.070 \\
\hline Y1 & 0.065 & 0.057 & 0.061 & 0.085 & 0.056 & 0.071 & 0.045 & 0.079 & 0.100 & 0.123 & 0.072 \\
\hline Y2 & 0.098 & 0.050 & 0.101 & 0.066 & 0.094 & 0.100 & 0.100 & 0.047 & 0.112 & 0.138 & 0.077 \\
\hline Y3 & 0.071 & 0.061 & 0.109 & 0.075 & 0.048 & 0.077 & 0.098 & 0.128 & 0.088 & 0.120 & 0.082 \\
\hline \multicolumn{12}{|c|}{ Panel G: Ohlson } \\
\hline$-\mathrm{Y3}$ & 0.36 & -0.35 & -0.57 & -0.69 & -0.69 & -0.82 & -0.98 & -1.05 & -1.13 & -1.36 & -1.08 \\
\hline$-\mathrm{Y} 2$ & 0.61 & -0.22 & -0.46 & -0.60 & -0.54 & -0.77 & -0.94 & -1.11 & -1.12 & -1.32 & -1.02 \\
\hline$-\mathrm{Y} 1$ & 0.99 & -0.04 & -0.30 & -0.52 & -0.64 & -0.67 & -0.89 & -1.13 & -1.01 & -1.33 & -0.94 \\
\hline Y1 & 1.18 & 0.10 & -0.29 & -0.46 & -0.56 & -0.63 & -0.84 & -0.99 & -0.86 & -1.32 & -0.85 \\
\hline Y2 & 1.03 & 0.16 & -0.32 & -0.48 & -0.52 & -0.60 & -0.79 & -0.88 & -0.81 & -1.18 & -0.84 \\
\hline Y3 & 1.14 & 0.04 & -0.28 & -0.40 & -0.59 & -0.56 & -0.60 & -0.83 & -0.81 & -1.16 & -0.83 \\
\hline \multicolumn{12}{|c|}{ Panel H: Altman } \\
\hline$-\mathrm{Y3}$ & 1.93 & 2.44 & 2.73 & 2.78 & 2.81 & 3.04 & 3.13 & 3.31 & 3.55 & 4.24 & 3.03 \\
\hline$-\mathrm{Y} 2$ & 1.76 & 2.34 & 2.60 & 2.68 & 2.77 & 2.88 & 3.06 & 3.31 & 3.46 & 4.33 & 2.99 \\
\hline$-Y 1$ & 1.43 & 2.15 & 2.44 & 2.56 & 2.63 & 2.77 & 2.96 & 3.35 & 3.35 & 4.35 & 2.92 \\
\hline $\mathrm{Y} 1$ & 1.37 & 2.10 & 2.45 & 2.54 & 2.64 & 2.76 & 2.93 & 3.15 & 3.22 & 4.07 & 2.86 \\
\hline $\mathrm{Y} 2$ & 1.52 & 2.16 & 2.48 & 2.59 & 2.68 & 2.76 & 2.84 & 3.08 & 3.08 & 3.85 & 2.84 \\
\hline Y3 & 1.53 & 2.30 & 2.51 & 2.47 & 2.70 & 2.72 & 2.71 & 3.09 & 3.03 & 3.66 & 2.84 \\
\hline
\end{tabular}


Table VIII: Cross-Sectional Tests. Panel A reports slopes and $t$-statistics (in parentheses) from Fama and MacBeth (1973) cross-sectional regressions of six-month buy-and-hold stock returns on different combinations of the following explanatory variables. Beta is the post-ranking beta of the beta-decile portfolio to which a firm belongs at the end of June of year $t$. Book-to-Market (B/M) is the log of book value of equity in December of year $t-1$ divided by market value of equity in December of year $t-1$. Firm size (Size) is the log of market capitalization measured in June of year $t$. For underfunded companies, the funding ratio $(F R)$ is the difference between fair value of plan assets and the projected benefit obligations in the fiscal year ending in year $t-1$, divided by market value of equity at the end of year $t-1$. For overfunded companies, $F R$ equals zero. $F R(+)$ is a dummy variable which is equal to one if the company is overfunded. Accruals (Acc.) are computed in December of year $t-1$, as in Sloan (1996). SUE are standardized unexpected earnings (the change in quarterly earnings per share from its value four quarters before, divided by the standard deviation of this variable over all the available observations for one company) in the most recent quarter. Ret -6 is the compound return over the past six months. In the regressions, the same level of $F R, F R(+)$, beta, Size, $\mathrm{B} / \mathrm{M}$ and Accruals is matched with six-month compounded returns in all the months from July of year $t$ to June of year $t+1$. SUE and Ret -6 change at the quarterly and monthly frequency, respectively. In Panel B the explanatory $F R^{\prime}$ replaces $F R$ and $F R(+)$. For over- and underfunded companies, $F R^{\prime}$ is the difference between fair value of plan assets and the projected benefit obligations in fiscal year ending in year $t-1$, divided by total assets at the end of year $t-1$. The reported slopes are computed as the time-series average of the slopes in monthly regressions of compound excess returns on the explanatory variables for July 1981 to December 2003. The $t$-statistics are computed using Newey-West (1987) standard errors with five lags of autocorrelation. The average number of stocks in the regressions is 1,252 .

\begin{tabular}{|c|c|c|c|c|c|c|c|}
\hline \multicolumn{8}{|c|}{ Panel A: FR } \\
\hline \multirow[t]{5}{*}{ FR } & Beta & $\mathrm{B} / \mathrm{M}$ & Size & Acc. & $\begin{array}{l}\text { SUE } \\
\end{array}$ & Ret_6 & $\overline{\mathrm{FR}(+)}$ \\
\hline & -1.79 & & & & & & \\
\hline & $(-1.13)$ & & & & & & \\
\hline & 1.89 & 1.50 & -0.07 & & & & \\
\hline & $(-0.82)$ & $(4.47)$ & $(-0.30)$ & & & & \\
\hline 7.82 & -1.25 & 1.56 & -0.08 & & & & 0.02 \\
\hline$(2.08)$ & $(-0.80)$ & $(4.76)$ & $(-0.36)$ & & & & $(0.08)$ \\
\hline 8.12 & -1.24 & 1.55 & -0.08 & -7.96 & & & 0.02 \\
\hline$(2.15)$ & $(-0.80)$ & $(4.83)$ & $(-0.36)$ & $(-3.50)$ & & & $(0.08)$ \\
\hline 7.75 & -1.07 & 1.64 & -0.10 & & 1.70 & & -0.01 \\
\hline$(2.08)$ & $(-0.69)$ & $(5.08)$ & $(-0.43)$ & & (10.48) & & $(-0.03)$ \\
\hline 7.63 & -1.54 & 1.43 & -0.10 & & & 0.03 & 0.04 \\
\hline \multirow[t]{3}{*}{$(2.03)$} & $(-1.05)$ & $(4.23)$ & $(-0.44)$ & & & $(2.70)$ & $(0.13)$ \\
\hline & -1.47 & 1.48 & -0.09 & -6.48 & 1.62 & 0.02 & \\
\hline & $(-0.97)$ & $(4.38)$ & $(-0.39)$ & $(-3.15)$ & (10.73) & $(1.57)$ & \\
\hline 7.84 & -1.40 & 1.53 & -0.11 & -6.62 & 1.61 & 0.02 & 0.01 \\
\hline$(2.10)$ & $(-0.96)$ & $(4.66)$ & $(-0.46)$ & $(-3.24)$ & (10.63) & $(1.58)$ & $(0.05)$ \\
\hline
\end{tabular}


Table VIII: Continued.

\begin{tabular}{ccccccc}
\hline \hline \multicolumn{7}{c}{ Panel B: $F R^{\prime}$} \\
\hline FR' & Beta & B/M & Size & Acc. & SUE & Ret_6 \\
\hline 9.12 & -1.17 & 1.54 & -0.06 & & & \\
$(2.33)$ & $(-0.75)$ & $(4.51)$ & $(-0.27)$ & & & \\
8.73 & -1.16 & 1.53 & -0.06 & -7.35 & & \\
$(2.25)$ & $(-0.74)$ & $(4.56)$ & $(-0.26)$ & $(-3.35)$ & & \\
8.75 & -0.99 & 1.63 & -0.08 & & 1.71 & \\
$(2.26)$ & $(-0.63)$ & $(4.83)$ & $(-0.33)$ & & $(10.50)$ & \\
8.98 & -1.46 & 1.42 & -0.08 & & & 0.03 \\
$(2.36)$ & $(-0.98)$ & $(4.01)$ & $(-0.35)$ & & & $(2.57)$ \\
8.45 & -1.32 & 1.52 & -0.08 & -6.05 & 1.63 & 0.02 \\
$(2.24)$ & $(-0.89)$ & $(4.41)$ & $(-0.36)$ & $(-3.11)$ & $(10.75)$ & $(1.45)$ \\
\hline \hline
\end{tabular}


Table IX: Double Sorting: Size and $\boldsymbol{F R}$. In July of year $t$, stocks are sorted by market capitalization as of June of year $t$, and five groups are formed according to the quintiles of the distribution (only NYSE stocks are used to find the breakpoints). Underfunded firms are independently sorted by the funding ratio $F R$ in December of year $t-1$ and five groups are formed according to the quintiles of the distribution of $F R$ for companies with $F R<0$. All overfunded firms $(F R \geq 0)$ are assigned to the OF group. Then, thirty value-weighted portfolios are formed in July of year $t$ from the intersection of the size and $F R$ sorts. $F R$ is the difference between the fair value of plan assets and Projected Benefit Obligation in fiscal year ending in year $t-1$, divided by the firm's capitalization in December of year $t-1$. The table reports the intercepts from time-series regressions of portfolio excess returns on the Fama-French factors EXM, HML, and SMB. The table also reports the estimated loadings on the three factors. The sample is July 1981 to December 2003. $t$-statistics are provided in parentheses.

\begin{tabular}{|c|c|c|c|c|c|c|c|c|c|c|c|c|}
\hline \multirow[b]{2}{*}{ Size } & \multicolumn{12}{|c|}{ FR Group } \\
\hline & 1 & 2 & 3 & 4 & 5 & OF & 1 & 2 & 3 & 4 & 5 & OF \\
\hline & \multicolumn{6}{|c|}{ Alphas } & \multicolumn{6}{|c|}{ Loadings on EXM } \\
\hline \multirow[t]{2}{*}{1} & -0.69 & -0.31 & -0.12 & -0.03 & -0.42 & -0.02 & 1.08 & 1.00 & 0.96 & 0.99 & 1.00 & 0.92 \\
\hline & $(-3.39)$ & $(-1.85)$ & $(-0.69)$ & $(-0.18)$ & $(-2.34)$ & $(-0.15)$ & $(21.43)$ & $(24.43)$ & $(22.86)$ & $(20.22)$ & $(22.84)$ & $(37.00)$ \\
\hline \multirow[t]{2}{*}{2} & -0.34 & -0.42 & 0.00 & -0.32 & -0.22 & -0.11 & 1.24 & 1.04 & 0.91 & 1.09 & 1.10 & 0.98 \\
\hline & $(-1.36)$ & $(-1.87)$ & $(0.02)$ & $(-1.82)$ & $(-1.19)$ & $(-0.99)$ & $(20.01)$ & $(18.62)$ & $(16.50)$ & $(24.95)$ & $(23.97)$ & $(37.43)$ \\
\hline \multirow[t]{2}{*}{3} & -0.94 & -0.49 & -0.06 & 0.14 & -0.06 & -0.09 & 1.37 & 1.12 & 1.05 & 1.00 & 1.02 & 1.00 \\
\hline & $(-3.21)$ & $(-2.14)$ & $(-0.33)$ & $(0.49)$ & $(-0.29)$ & $(-0.81)$ & $(18.98)$ & $(20.08)$ & $(23.59)$ & $(13.91)$ & $(20.71)$ & $(36.80)$ \\
\hline \multirow[t]{2}{*}{4} & -0.59 & -0.03 & 0.17 & -0.19 & -0.08 & -0.18 & 1.32 & 1.10 & 0.93 & 1.09 & 1.02 & 1.07 \\
\hline & $(-1.49)$ & $(-0.15)$ & $(0.98)$ & $(-0.91)$ & $(-0.36)$ & $(-1.89)$ & $(13.64)$ & (19.37) & $(22.01)$ & $(20.60)$ & $(19.45)$ & $(44.28)$ \\
\hline \multirow[t]{3}{*}{5} & -0.38 & -0.09 & 0.40 & 0.01 & 0.06 & -0.03 & 1.36 & 0.97 & 0.96 & 1.05 & 0.98 & 0.98 \\
\hline & $(-1.09)$ & $(-0.35)$ & $(1.83)$ & $(0.03)$ & $(0.42)$ & $(-0.46)$ & $(15.65)$ & (14.98) & $(17.85)$ & $(18.39)$ & $(28.83)$ & $(68.67)$ \\
\hline & \multicolumn{6}{|c|}{ Loadings on HML } & \multicolumn{6}{|c|}{ Loadings on SMB } \\
\hline \multirow[t]{2}{*}{1} & 0.84 & 0.76 & 0.54 & 0.58 & 0.47 & 0.59 & 0.91 & 0.82 & 0.76 & 0.75 & 0.79 & 0.73 \\
\hline & $(10.81)$ & $(12.05)$ & $(8.45)$ & $(7.70)$ & $(6.93)$ & $(15.47)$ & $(14.00)$ & $(15.45)$ & $(14.05)$ & (11.98) & $(13.88)$ & $(22.70)$ \\
\hline \multirow[t]{2}{*}{2} & 0.78 & 0.76 & 0.61 & 0.52 & 0.39 & 0.60 & 0.68 & 0.68 & 0.58 & 0.64 & 0.47 & 0.49 \\
\hline & $(8.17)$ & $(8.85)$ & $(7.26)$ & $(7.75)$ & $(5.56)$ & (14.77) & $(8.45)$ & $(9.40)$ & $(8.18)$ & $(11.45)$ & $(7.94)$ & $(14.32)$ \\
\hline \multirow[t]{2}{*}{3} & 0.92 & 0.71 & 0.53 & 0.35 & 0.47 & 0.54 & 0.41 & 0.36 & 0.30 & 0.20 & 0.30 & 0.18 \\
\hline & $(8.30)$ & $(8.29)$ & $(7.80)$ & $(3.18)$ & $(6.19)$ & (13.00) & $(4.40)$ & $(5.04)$ & $(5.16)$ & $(2.19)$ & $(4.65)$ & $(5.01)$ \\
\hline \multirow[t]{2}{*}{4} & 0.87 & 0.44 & 0.38 & 0.46 & -0.01 & 0.55 & 0.30 & 0.08 & 0.18 & 0.21 & 0.13 & -0.03 \\
\hline & $(5.86)$ & $(5.05)$ & $(5.84)$ & $(5.69)$ & $(-0.15)$ & (14.95) & $(2.38)$ & $(1.06)$ & $(3.36)$ & (3.09) & (1.98) & $(-0.95)$ \\
\hline \multirow[t]{2}{*}{5} & 0.71 & 0.66 & 0.23 & 0.08 & -0.02 & 0.13 & -0.05 & 0.00 & -0.17 & -0.23 & -0.37 & -0.32 \\
\hline & $(4.95)$ & (6.73) & $(2.79)$ & $(0.87)$ & $(-0.46)$ & $(5.95)$ & $(-0.40)$ & $(-0.04)$ & $(-2.51)$ & $(-3.23)$ & $(-8.54)$ & $(-17.22)$ \\
\hline
\end{tabular}




\section{References}

[1] Altman, Edward I., 1968, Financial ratios, discriminant analysis, and the prediction of corporate Bankruptcy, Journal of Finance 23, 589-609.

[2] Ball, R., and P. Brown, 1968, An empirical evaluation of accounting income numbers, Journal of Accounting Research 6, 159-178.

[3] Banz, Rolf, and W. J. Breen, 1986, Sample dependent results using accounting and market data: some evidence, Journal of Finance 41, 779-793.

[4] Berk, Jonathan, 1995, A critique of size related anomalies, Review of Financial Studies 8, $275-286$.

[5] Bergstresser, Daniel, Mihir Desai, and Joshua Rauh, 2004, Earnings manipulations and investment decisions: evidence from sponsored pension plans, NBER working paper No. 10543.

[6] Bernard, V., and J. Thomas, 1990, Evidence that stock prices do not fully reflect the implications of current earnings for future earnings, Journal of Accounting and Economics 13, 305-341.

[7] Bulow, Jeremy, Randall Morck, and Lawrence H. Summers, 1987, How does the market value unfunded pension liabilities?, in Z. Bodie, J. Shoven and D. Wise, eds.: Issues in Pension Economics (Chicago: UCP).

[8] Chan, K. C., N. Jegadeesh, and J. Lakonishok, 1996, Momentum strategies, Journal of Finance $51,1681-1713$.

[9] Chan, Konan, Louis K. C. Chan, Narismhan Jegadeesh, and Josef Lakonishok, 2004, Earnings quality and stock returns, Journal of Business, forthcoming.

[10] Dichev, Ilia D., 1998, Is the risk of bankruptcy a systematic risk?, Journal of Finance 53, 1131-1147.

[11] Fama, Eugene, 1970, Efficient capital markets: a review of theory and empirical work, Journal of Finance 25, 383-417.

[12] Fama, Eugene, 1991, Efficient capital markets: II, Journal of Finance 46, 1575-1617. 
[13] Fama, E., and K. French, 1992, The cross-section of expected stock returns, Journal of Finance $47,427-465$.

[14] Fama, E., and K. French, 1993, Common risk factors in the returns on stocks and bonds, Journal of Financial Economics 33, 3-56.

[15] Fama, E., and J. MacBeth, 1973, Risk, return, and equilibrium: empirical tests, Journal of Political Economy 81, 607-636.

[16] Feldstein, Martin, and Randall Morck, 1983, Pension funding decisions, interest rate assumptions and share prices, in Zvi Bodie and John B. Shoven, eds.: Financial Aspects of the U.S. Pension System (Chicago: UCP).

[17] Feldstein, Martin, and Stephanie Seligman, 1981, Pension funding, share prices, and national savings, Journal of Finance 36, 801-824.

[18] Hong, Harrison, Terence Lim, and Jeremy Stein, 2000, Bad news travels slowly: size, analyst coverage, and the profitability of momentum strategies, Journal of Finance 55, 265-295.

[19] Jegadeesh, N., and S. Titman, 1993, Returns to buying winners and selling losers: implications for stock market efficiency, Journal of Finance 48, 65-91.

[20] Lakonishok, J., A. Shleifer, and R. Vishny, 1994, Contrarian investment, extrapolation, and risk, Journal of Finance 50, 1541-1578.

[21] Ohlson, James, 1980, Financial ratios and the probabilistic prediction of bankruptcy, Journal of Accounting Research 18, 109-131.

[22] Newey, W., and K. West, 1987, A simple positive-definite heteroskedasticity and autocorrelation consistent covariance matrix, Econometrica 55, 703-708.

[23] Pastor, Lubos, and Robert Stambaugh, 2003, Liquidity risk and expected stock returns, Journal of Political Economy 111, 642-685.

[24] Sloan, R. G., 1996, Do stock prices fully reflect the information in accruals and cash flows about future earnings?, Accounting Review 71, 289-315.

[25] Stein, J. C., 1989, Efficient capital markets, inefficient firms: a model of myopic corporate behavior, Quarterly Journal of Economics 104, 773-787. 


\section{Notes}

${ }^{1}$ Although there is a large variety of employer pension programs, they are usually classified into one of two broad types: defined contributions (DC) and defined benefit (DB) pension plans. In a DC plan, such as a 401(k), each employee has an account in which the employer, and possibly the employee, makes regular contributions. The employee has some degree of discretion concerning the type of asset in which these contributions are invested. The total benefit the employee receives at retirement depends on the level of contributions and the performance of the portfolio in which they have been invested. In contrast, in a DB plan the benefit that the employee is entitled to at retirement is determined by a formula which takes into account the employee's years of service, present and future salaries, etc. The employer must set aside funds to meet benefits at retirement. These contributions are invested in assets at the sole discretion of the employer.

${ }^{2}$ The fundamental source of pension accounting regulation is the Statement of Financial Accounting Standards number 87 (SFAS 87) issued in 1985, whose principles are consistent with previous accounting practices.

${ }^{3}$ According to SFAS 87 , the amortization period will be the average remaining service period of active employees expected to receive benefits under the plan. If all, or almost all, of a plan's participants are inactive, the average remaining life expectancy of the inactive participants shall be used instead of average remaining service.

${ }^{4}$ In computing the funding status, ERISA compares the market value of plan assets to the present value of future pension obligations. For a plan that is less than $90 \%$ funded, ERISA requires the sponsoring firm to make an additional contribution to the plan to reduce the funding deficiency within three to five years. There are some exceptions, however. If a plan is over $80 \%$ funded today, and was more than $90 \%$ funded for the past two years, the additional contribution requirement is 
waived. Furthermore, companies may request a hardship waiver or an extension period over which to meet the normal and additional contribution requirements.

${ }^{5}$ In fact, the approach of Bulow, Morck, and Summers (1987) is somewhat different as they take into account the endogeneity issues implied by regressing market value on variables, such as the pension plan funding status, that are simultaneously determined with the market value itself. These authors adopt an event study methodology, and test whether an exogenous change in interest rates has a different impact on the market value of companies with different levels of funding in their pension plans. However, this methodology is not suitable to conclude whether the extent to which the market incorporates information into prices is consistent with correct valuation.

${ }^{6}$ One could see this fact simply by multiplying and dividing $F R$ by the book value, that is,

$$
F R=\frac{F V P A-P B O}{B o o k} \frac{B o o k}{M k t C a p}
$$

For a given level of the first ratio and positive $F R$, a higher FR corresponds to a higher B/M ratio. We are grateful to the referee for making this point, which affected the final choice of our research design.

${ }^{7}$ The latest aggregate data about portfolio allocation of DB pension plans, along with other aggregate statistics on U.S. pension plans, can be found in the "Private Pension Plan Bulletin Abstract of 1998 Form 5500 Annual Reports," which is published by the U.S. Department of Labor.

${ }^{8}$ The time series of the market return, HML, SMB, and the momentum factor (UMD) come from Prof. K. French's website, where the details on the construction of these portfolios are provided.

${ }^{9}$ Concerning this last point, we have separate evidence, available upon request, that the average $F R$ for portfolio one five years after formation is still as low as $-26 \%$. 
${ }^{10}$ Using a six-month moving average of the revision in Equation (7), while decreasing the number of stocks for which we have nonmissing values, would not change the results.

${ }^{11}$ Following Dichev (1998), we define Altman's (1968) Z-score as: Z = 1.2(working capital/total assets $)+1.4($ retained earnings/total assets $)+3.3($ earnings before interests and taxes/total assets $)+0.6$ (market value of equity/book value of total liabilities $)+($ sales/total assets $)$. Ohlson's (1980) index is defined as: $\mathrm{O}=-1.32-0.407 \log ($ total assets $)+6.03$ (total liabilities/total assets) - 1.43(working capital/total assets) + 0.076(current liabilities/current assets) $-1.72(1$ if total liabilities $>$ total assets, else 0) - 2.37(net income/total assets) - 1.83(funds from operations/total liabilities $)+0.285(1$ if net loss for last two years, else 0$)-0.521\left(\right.$ net income $_{t}-$ net income t-1 $\left._{t}\right) /(\mid$ net income $_{t}|+|$ net income $\left.t-1 \mid\right)$.

${ }^{12}$ Book-to-Market is computed as Compustat book value of shareholders' equity in fiscal year $t-1$ (item 216) divided by market capitalization in December of year $t-1$.

${ }^{13}$ To maximize the number of observations in this exercise, we standardize earnings surprises by the standard deviation of all available surprises for one firm.

${ }^{14}$ Hence, to be included in our tests in July of year $t$, a firm needs to have a CRSP stock price for December of year $t-1$ and June of year $t$. The stock must also have monthly returns for at least 24 of the 60 months preceding July of year $t$ in order to compute pre-ranking beta estimates. Moreover, the accounting variables needed to compute B/M, FR, accruals, and SUE must also be available. Finally, we drop observations for which $F R, \mathrm{~B} / \mathrm{M}$, size, accruals, and SUE are more than three standard deviations away from the mean.

${ }^{15}$ We have separate portfolio results (available upon request) indicating that severely underfunded firms still display large negative alphas, when $F R^{\prime}$, rather than $F R$, is used as the sorting variable. For example, the alpha for the equally weighted portfolio one from the three-factor model is $-0.42 \%$ 
$(t$-statistic $=-2.13)$. In general, the sorting by $F R^{\prime}$ produces alphas that are smaller in absolute value than the sorting by $F R$. As argued in the introduction, we impute this difference to the fact that using market capitalization as the denominator identifies companies that are more likely to be in a situation of financial distress, and for which there is less information diffusion, given their smaller size. Financial distress would magnify mispricing through the effect of credit constraints. The same reduction in cash flows, which is needed to fund the plan, may have a larger impact on the value of a firm with restricted access to credit.

${ }^{16}$ Evidence of managers' strategic behavior with respect to pension items is provided by Bergstresser, Desai, and Rau (2004). Specifically, these authors show that managers alter the assumed rate of return on pension assets in order to manipulate earnings. 


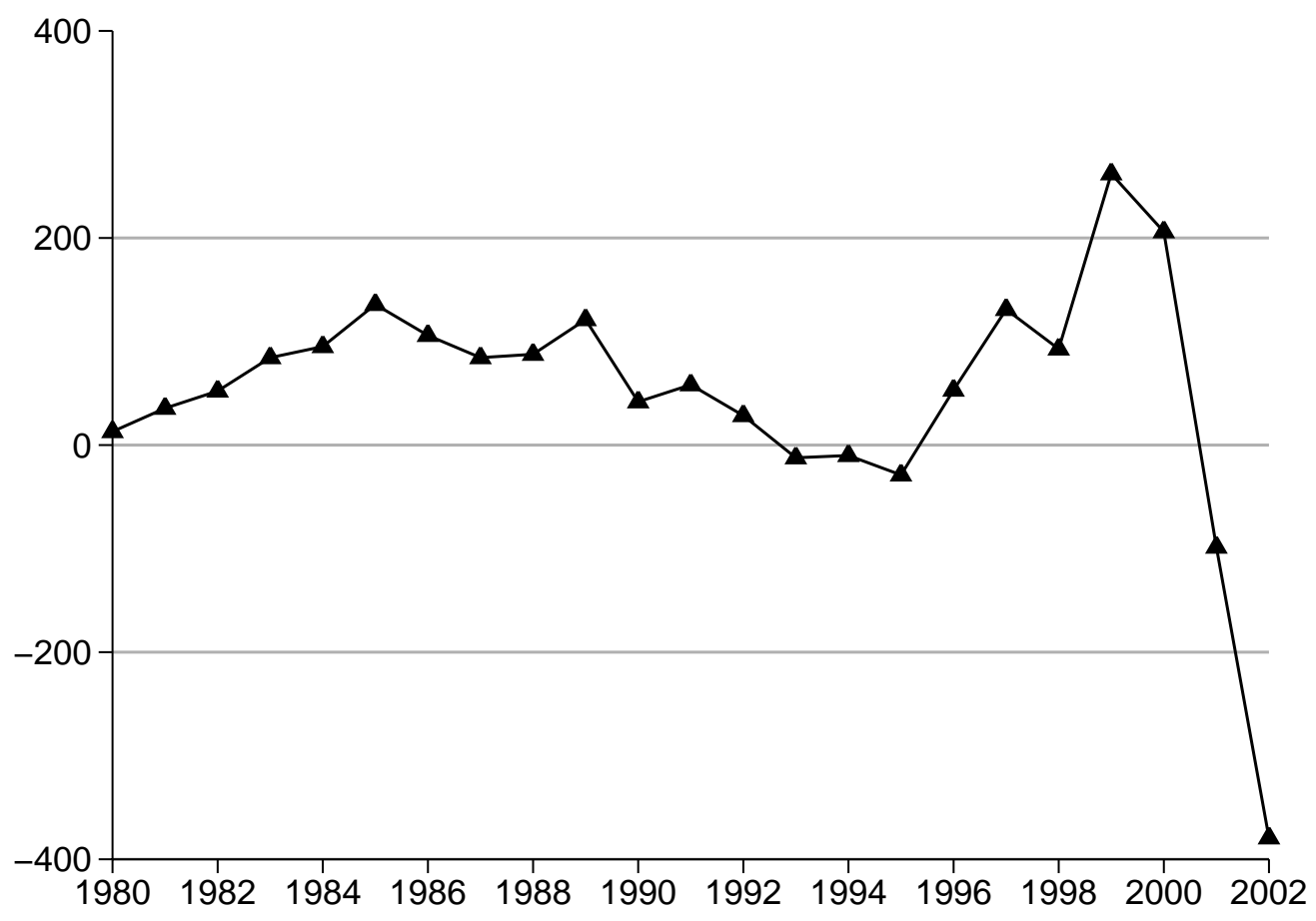

Figure 1: Aggregate pension plan funding over time. The graph reports the difference between aggregate assets (FVPA) and aggregate benefits (PBO), for all the companies in Compustat with available observations. The quantities are expressed in billions of dollars. 